Policy Research Working Paper

On the Intersectoral

Migration of Agricultural

Labor

Donald Larson

Yair Mundlak

The World Bank

International Economics Department

Commodity Policy and Analysis Unit

February 1995

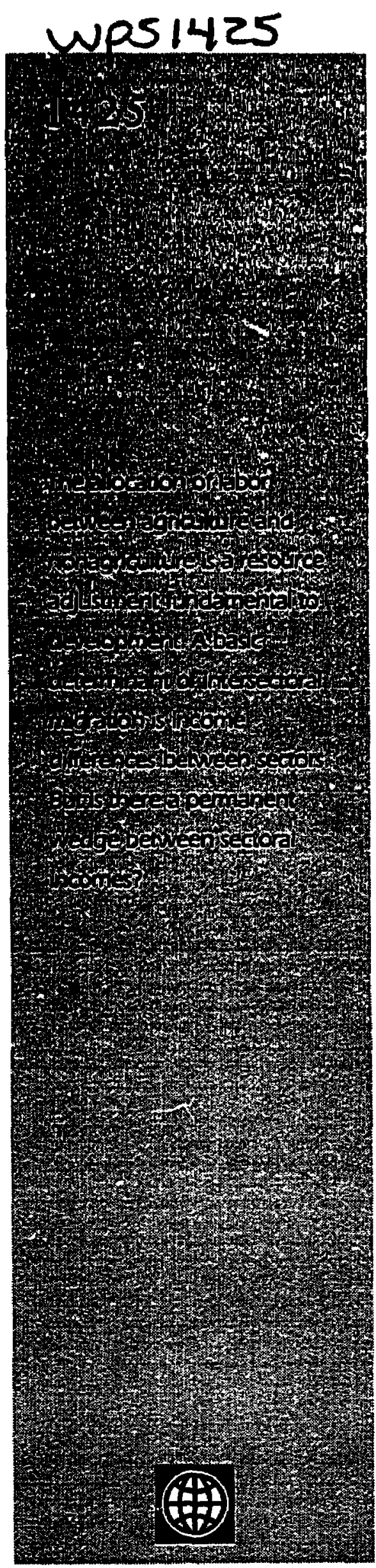


Policy Research Working Paper 1425

\section{Summary findings}

Labor is the single most important factor in determining national income. As economies grow, agricultural labor declines as a share of total labor and converges to a level of 2 or 3 percent. Off-farm migration facilitates the development of nonagriculture, but historically the process spans decades.

Larson and Mundlak argue that the pace of the process is a fundamental outcome of a dynamic equilibrium based on expectations of lifetime earnings and the cost of migration. The authors present an empirical model of the determinants of intersectoral migration. One fundamental determinant is income differences across sectors. As such, migration should stop when income differences reach a certain level.

Larson and Mundlak provide a method of measuring the level at which intersectoral migration will cease. While there are credible reasons for a permanent difference to exist between sectoral incomes, the authors find no empirical evidence of a permanent wedge.

This paper - a product of the Commodity Policy and Analysis Unit, International Economics Department - is part of a larger effort in the department to understand and measure the determinants of economic growth. The study was funded by the Bank's Research Support Budget under the research project "Determinants of Agricultural Growth" (RPO 679-03). Copies of this paper are available free from the World Bank, 1818 H Street NW, Washington, DC 20433. Please contact Jean Jacobson, room R2-075, extension 33710 (45 pages). February 1995.

The Policy Research Working Paper Series dioveminates ibe fondings of work in progress to encourage the exchange of ideas about development isones. Ar objective of the series is to get the findings out quiably, even if the presentations ane less than fully polished. The papers cany the namas of the aubors and should be used and cited accordingty. The fundings, interpretations, and conclusions are the authors' oum and should not be attribusted to the World Bank, its Executive Bowd of Directors, or any of its member coustries. 
On the inter-sectoral migration of agricultural labor

$$
\text { by }
$$

$$
\text { Donald Larson and Yair Mundlak }
$$




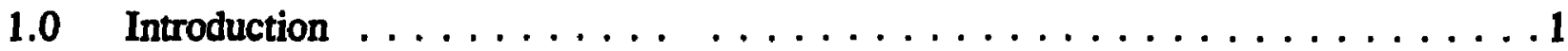

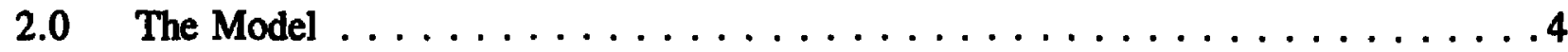

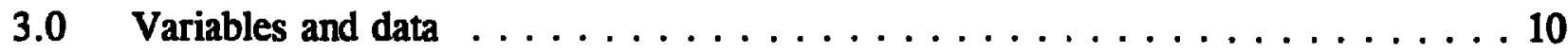

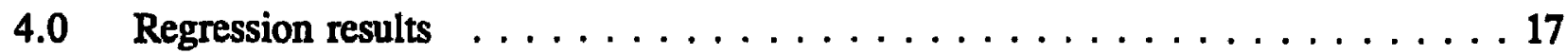

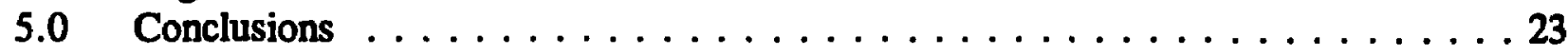

Annex 1: Ratio of non-agriculture to agriculture average labor products . . . . . . 29

Annex 2: Ratio of non-agricultural labor force to agricultural labor force . . . . . 32

Annex 3: Average annual labor force growth rates (decade average) . . . . . . . 35

Annex 4: Migration version 1 and 2 1950-90 (\% per annum) $\ldots \ldots \ldots \ldots . \ldots . \ldots 38$

Annex 5: Migration version 3 and 4 1950-90 (\% per annum) $\ldots \ldots \ldots \ldots$. . . 42

\section{Figures}

Figure 1.1: Agriculture's share of labor $\ldots \ldots \ldots \ldots \ldots \ldots \ldots \ldots \ldots$

Figure 2.1: Differences in average income motivates migration . . . . . . . . 9

Figure 2.2: Differences in the distribution of income between sectors may also affect migration rates $\ldots \ldots \ldots \ldots \ldots \ldots$

Figure 3.1: Persistence of migration rates, 1950s and 1960s . . . . . . . . 12

Figure 3.2: Persistence of migration rates, 1970 s and $1980 \mathrm{~s} \ldots \ldots \ldots \ldots \ldots$

Figure 3.3: Ratio of sectoral average incomes $\ldots \ldots \ldots \ldots \ldots \ldots$

Tables

Table 3.1: Average sample means for selected regression variables $\ldots \ldots \ldots \ldots \ldots 17$

Table 4.1: Regression results for full model . . . . . . . . . . . . . 18

Table 4.2: Regression results for constrained versions of the model . . . . . . . . 19

Table 4.3: Regression results under alternative definitions of migration $\ldots \ldots \ldots 22$

Table 4.4: Effects of development variable on parameter estimates . . . . . . 23

Table 4.5: $\quad$ Effects of freedom variable on parameter estimates . . . . . . . . . 24 


\title{
On the inter-sectoral migration of agricultural labor
}

by

\author{
Donald Larson and Yair Mundlak
}

\subsection{Introduction}

Economic development, structural change and economic reforms require changes in resource allocation. In turn the pace and frequently the success of these processes depend crucially on the speed of the resource adjustment. This paper deals with a fundamental resource adjustment - the allocation of the labor force between agriculture and non-agriculture. Labor is the most important single factor in determining national income and in most industries its factor share exceeds $\mathbf{5 0}$ percent. Further, as economies develop, the share of the agricultural labor in total labor declines and converges to a level of two or three percent. (See Figure 1.1.) As such, off-farm migration facilitates the development of non-agriculture. Historically, the decline in the share of agriculture in the labor force has occurred over a long time period. This raises the question: what determines the pace of the process? Is it due mainly to market imperfections or is it a fundamental outcome of a dynamic equilibrium?

In this paper we attempt to answer this question by examining the determinants of off- farm migration and to quantify their importance. The basic determinant of intersectoral migration is the existence of income differences between sectors. Consistent with this is the notion that migration should come to a halt when intersectiral income differentials decline to some level. Whether they should completely disappear or there should be some permanent wedge in intersectoral income is a question implicitly discussed by raising other issues which affect migration, such as uncertainty. This 
issue can be settled empirically and it is our finding that the process results eventually in income equality across sectors.

To capture empirically the effect of income on migration it is desirable to have a sample with a big spread in this variable. Such a spread is found in cross-country data as studied in Mundlak (1979). Since then, the data base has expanded considerably and that makes it possible to examine the stability of the process and to take up additional topics. In this respect the study differs from studies using micro data or time series data for a given country.

The intersectoral allocation of labor is the center piece in the dual economy analysis of Arthur Lewis (1954) and subsequent works such as Fei and Ranis (1964) and Jorgenson (1961). The main message of these studies is that in the process of development, labor moves to the modern sector which facilitates development. However, in developing this idea it is assumed that the modern sector

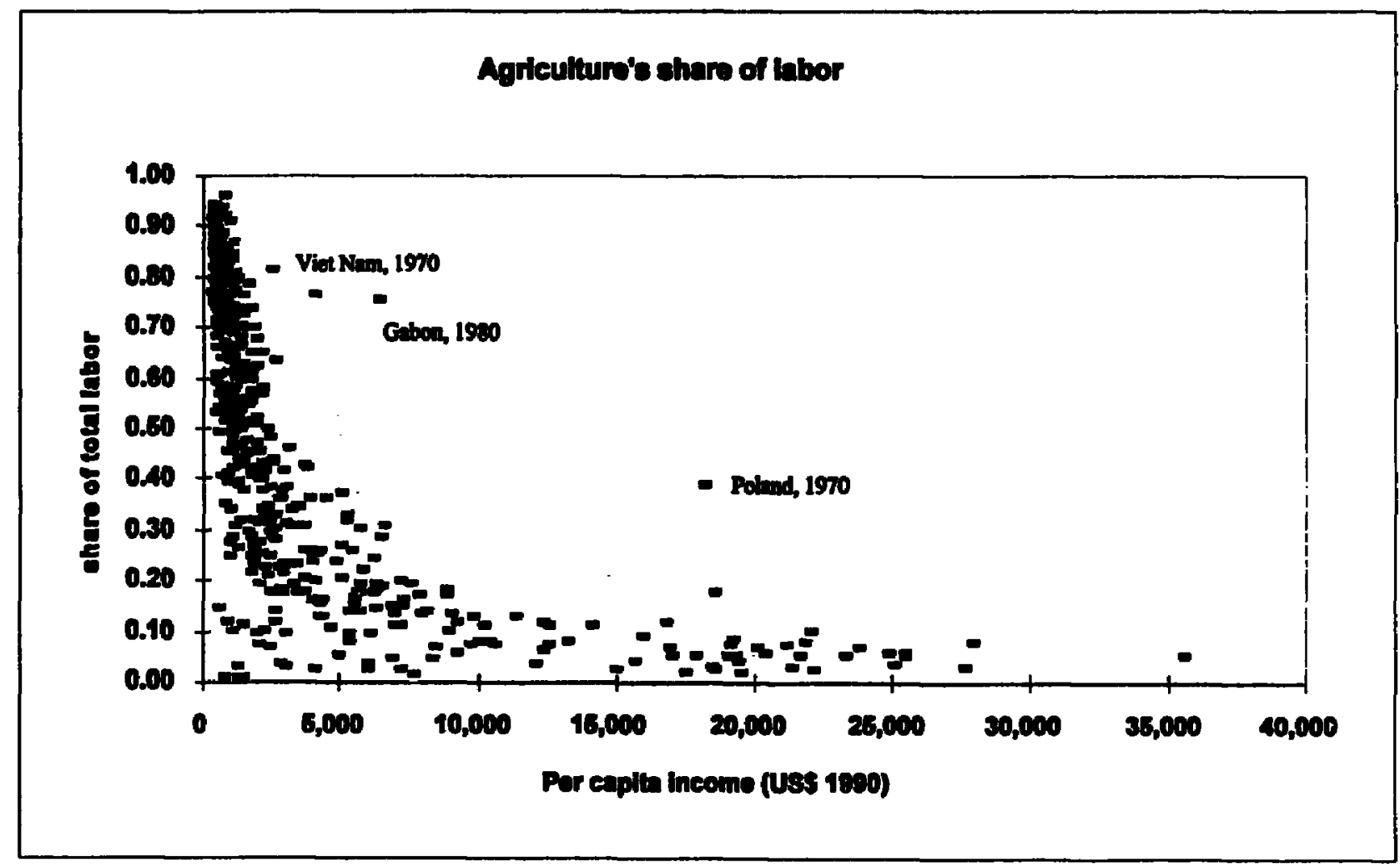

Digure 1.1: Agriculture's share of labor declines as conntribu develop. 
faces perfectly elastic labor supply, originating in the traditional or rural sector. This view is inconsistent with the idea that migration is determined in response to varying income differentials and that labor is productive in all sectors of the economy. Although perfectly elastic labor supply is not essential for the development of the dual economy, the difference in views is of cardinal importance since it is a key factor in understanding the dynamics of the economy. Specifically, when migration responds to income differentials, the dynamics of the economy is determined by the economic environment. As such it is also affected by economic policies. The country and time coverage of this study provides a pertinent global view of this process. In this sense, the study of intersectoral allocation of labor is instructive also with respect to other resources which may be more difficult to capture empirically.

Migration is an old topic in economics and can be traced back to Adam Smith (1776) who discussed its causes and consequences. Various aspects of the topic have been widely discussed and surveyed: Stark (1991), Williamson (1990), Molho (1986), Yap (1977) and Greenwood (1975). Empirical studies have been conducted at different levels of aggregation, from households to countries, covering occupational choice, international and intersectoral migration. Much of the work examines the importance of various attributes of the migration decisions such as education, uncertainty age and gender. However, Hicks (1932, p.76), as quored by Molho (1986), asserts that "... differences in net economic advantage, chiefly in wages, are the main causes of migration" Indeed, a large portion of the literature focuses on wage disparities, for example Williamson (1990, p. 186), Squire (1981), Fishlow (1972) and Bellante (1979).

In this study we examine theoretically and empirically the cause of off-farm migration and its role in development. We argue, however, that income, rather than wage differentials determine the intersectoral migration. The two measures, wage and income differentials, are likely to be correlated 
but they represent different concepts and have different repercussions as will become clear from the subsequent discussion.

\subsection{The model}

The point of departure is the theory of labor supply where the labor supply of an individual is determined as a choice between leisure and consumption. Consumption is financed in full or in part by income derived from work. The individual also has to chose among various occupations that differ in skill requirements, income and location. Location has two dimensions, work and residence. The latter affects the consumption choice in terms of availability of goods and services, their quality and prices.

In terms of optimization framework, we imagine an individual maximizing his remaining-life time utility derived from consumption and leisure, subject to the market opportunities'. The outcome of this optimization is summarized in terms of an indirect utility function computed for each of the occupational alternatives. The choice reflects the occupation with the perceived highest utility. As such, the choice between farm and off-farm employment is influenced by the untersectoral income differential. When income in non-agriculture is higher than in agriculture, labor will move out of agriculture.

By assumption, the decision to migrate is based on lifetime income and as such the age (g) of the individual is important. Other things equal, the younger the person is, the longer is the period over which he will benefit from the higher income in the new occupation. Further, changing occupation and changing sectors is costly. This cost of migration may also be lower for younger workers than for the old - especially for those workers who do not support additional family

ISjaastad (1962) first postulated that migrants base their decision on a discounted stream of costs and benefits. 
members. The costs and benefits may also relate to other attributes specific to the individual ( $z$ ) such as education, gender, and the amount of information available to the individual on costs and opportunities. Education may increase the probability of being employed and may also reduce the cost of migration. Another variable which affects the cost of migration is the distance (d), broadly defined, to the new employment opportunities ${ }^{2}$. The act of traveling physical distance generates migration costs. However, there are also other costs related to distance including the cost of acquiring information about distant locations, changes in regional languages and culture, lack of extended family support in distant areas, etc. We take distance, broadly defined, to include these additional factors. The larger is the distance, the larger is the cost. The importance of the distance depends on the state of the development of the economy $(y)$ reflected in the development of infrastructure, such as roads, motorization and communication, all of which brings the remote areas closer to labor markets. To summarize, the cost of migration is written as $c(g, z, d, y)$.

To formulate the choice, let

$$
v(g, z, j \mid .)=v\left[p_{j}, w_{j}, g, z, c_{j}\left(d_{j}, g, z, y\right)\right]
$$

be the level of utility an individual of age $g$ with attributes $z$ can expect to achieve in occupation $j$ with expected income $w_{f}$, prices of consumption goods $p_{j}$ and cost of migration $c_{j}$. The cost of migration represent the cost involved in moving from the present occupation to the jth alternative. It is zero if the individual remains in the present occupation.

Let $\mathrm{T}$ be the "retirement" age, and write the discounted stream of utility evaluated for an individual of age $\boldsymbol{g}$ in alternative $\boldsymbol{j}$ as:

${ }^{2}$ Ravenstein's 1889 "Laws of Migration" state that migration falls with distance. 


$$
V(g, z, j) \cdot \int_{\varepsilon}^{r} \varepsilon^{n} v(g, z, J)(\tau) d \tau
$$

Let $j=a, n$ be the sectoral subseript labels for agriculture and non-agriculture respectively, the criterion for off-farm migration can be written as

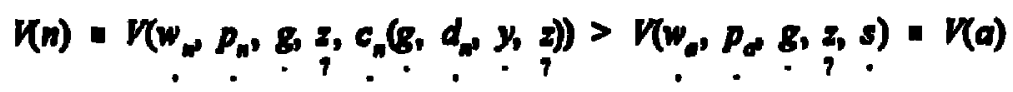

where the signs indicate the sign of the partial derivatives. Clearly, the future time path of the arguments of the indirect utility functions, or the state variables, is unlonown and the choice is based on expected values.

To develop the migration fimction, we introduce an index function $h$ which takes on values of either 0 or 1 to be determined by:

$$
[V,(n)-V,(a)] h,(a, n) \geq 0
$$

where $V_{1}(n)$ and $V_{1}(a)$ are the indirect utility function for an individual i evaluated for the conditions in non-agriculture and agriculture respectively. When the bracketed term is positive the individual benefits from migration and the function $h(a, n)$ talkes on a value of one, otherwise its value is zero. Labor can also migrate into agriculture and to account for it, the sectoral notation in (2.4) is reversed.

$$
\left[V_{1}(a)-V_{1}(a)\right] h_{1}(n, a) \geq 0
$$

Summing over the sectoral labor force gives the number of migrants:

$$
M(a, n)-\sum_{1}^{L} h(a, n)-\sum_{1}^{L} h(\dot{n}, a)
$$


$M(a, n)$ is a function of the arguments of the indirect utilty functions in the two sectors, labeled $\varphi(a, n)$. By definition, it is also a function of the size of the labor force in the origin. As most of the migration is out of agriculture, the migration will increase with the size of the labor force in agriculture. However, the size of the labor force in the destination also matters. Other things equal, the larger the labor market at the destination, the easier it shuuld be for the new migrant to obtain a job. Taking these considerations into account and maintaining the constant-returns-to-scale property with respect to the sectoral labor results in:

$$
M(t)=\Phi(a, n) L_{\alpha}(t)^{1+\varphi} L_{n}(t)^{\varphi}, \text { for } 0 \leq \beta \leq 1
$$

where $L_{a}(t)$ and $L_{n}(t)$ are the labor force in agriculture and non-agriculture respectively.

To introduce the functional form used in the empirical analysis we divide both sides by $L_{a}(t-1)$, and label the migration as a proportion of agricultural labor by $m \cdot M / L_{a}$, the sectoral labur ratio by $m L_{n} / L_{a}$ and the ratio of sectoral income by $8 \cdot w_{n} / w_{a}$. An interesting reference point for 8 is the value at which there would be no migration. A natural value is 8.1 the point at which sectoral incomes are equal. However as we discuss below, there are several reasons for this value to differ from 1 . To evaluate this issue empirically, we introduce a parameter, $k$, to measure the permanent wedge between wages in the two sectors. When $k-0$, migration ceases when sectoral incomes are equal, that is when 8.1 .

In the empirical analysis we use lagged values for the labor force and note that in the absence of migration, $L_{\sigma}(t)^{(1-\beta)} L_{n}(t)^{\beta}=L_{a}(t-1)^{(1-\theta)} L_{n}(t-1)^{\beta}(I+n)$ where $n$ is the natural rate of growth of the labor force. Incorporating these modifications, we obcain the functional form used empirically :

$$
m(t)=b_{0}[8(t-1)-1-k]^{h_{1}} r(t-1)^{b_{2}}=(t-1)^{b}+(1+k)+u,
$$


where : represents the exogenous state variables.

In interpreting the equation it is important to realize that a person moving to non-agrisulture is unlikely to immediately receive the average income of that sector. Further, it is well known that migration takes place in spite of existing unemployment in non-agriculture and the migrant may find himself unemployed. In fact, in country studies of migration where measures of unemployment were available, it was found that unemployment had a depressing effect on the rate of migration -Mundlak, Cavallo and Domenech (1989) for Argentina, Coeymans \& Mundlak (1993) for Chile. Furthermore, the first job a migrant takes after migration is likely to be low paying and therefore kept for a relatively short duration. It is here that the criterion of lifetime income is important, since the lower income in the initial period after migration may be compensated by higher income later on. A similar argument also applies to migrants who are initially unemployed. Todaro (1969) suggested that the decision to migrate takes place according to expected, rather than actual, wage rate, where the expected wage is the product of the wage rate and the probability of getting a job. When the wage differential is high, it pays to migrate even when the probability of getting a job is less than one.

The use of expected income alone as a decision criterion is applicable to risk-neutral individuals. It would be preferable to model the higher momements of the perceived income distributions of the two sectors since risk-averse individuals will also consider the stability of income. As a practical matter, only average labor income or wages are available as idicators of relative expected income. In our application, we choose to work with average labor income since it provides a better measure of average consumption and therefore relative utiltiy levels. Broadly speaking, by comparing average income levels we are guaging the distance between the income distributions in the 
two sectors. The greater the

distance, other things being equal, the greater the rate of migration as illustrated by Figure 2.1. Still, if income in agriculture is less stable than in non-agriculture, migration will take place even if

incomes in both sectors are equal, as illustrated by Figure 2.2 .

Fortunately, the effect of the unknown differences in income distributiuons can be recovered empirically since this implies a negative value for $k$ in (2.7). On the other hand, if the unemployment in nonagriculture
Avarage lncomes difor bowwew agrlowhre and non-agrloulme

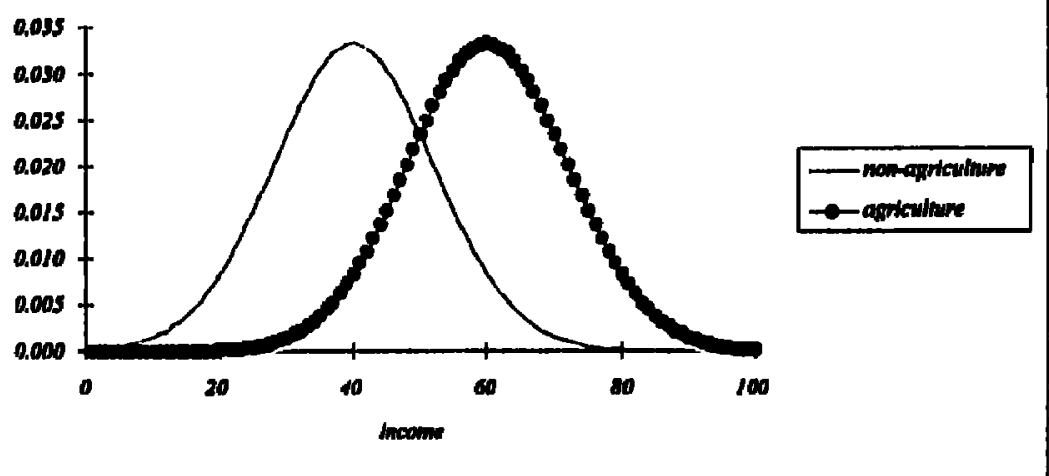

Figure 2.1: Differences in average income motivates migration.

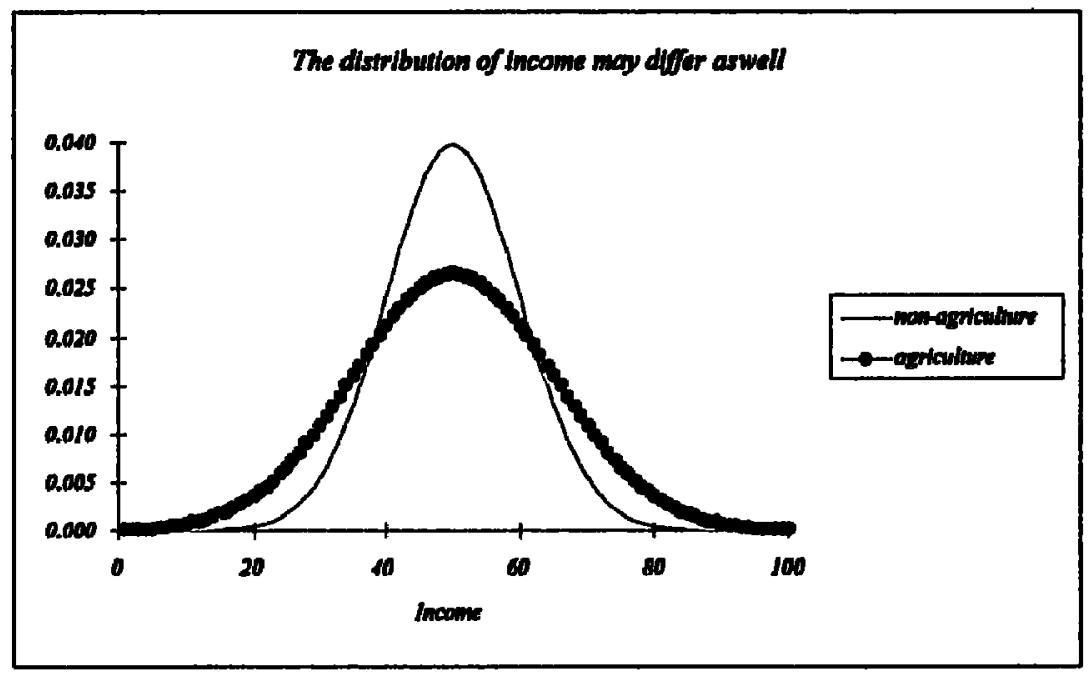

Figure 2.2: $\mathrm{n}$ :ferences in the distribution of income between sectors may also affect migration rates.

is high, and the individual is risk averse, the value of $k$ will be positive so that migration will stop at a point where 8 is larger than one ${ }^{3}$.

Another consideration for migration and risk is the relationship between the migrant and the household. Paison (1994), in her study of migration in Thailand maintains that, when the household

${ }^{3}$ In the study of Chile by Coeymans \& Mundlak, unemployment in non-agriculture appeared as a separate variable. Its elasticity was significantly higher than that of the income differential, indicating that unemployment carried more weight - a finding consistent with risk aversion. 
is taken as the decision making unit, migration can diversify the income source of the family and reduce its variability. By sending some members of the family to other locations where income is subject to different shocks than those at home, the family can generate a portfolio effect when those shocks are negatively correlated. The ability of the family to off-set risk through diversification of family labor should reduce the wedge between sector incomes.

Finally, a worker may migrate even when the income he receives in non-agriculture is lower than in agriculture if he can enhance the welfare of his children. For example, Tcha (1992) concluded that families frequently migrated in Korea to take advantage of better schooling and thereby enhance career opportunities for their children. In this case, the integral in (2.2) also carries across the life-time of the descendants.

In this study the measure of income is the average labor productivity, obtained by dividing output by the labor force and not by the labor employed. Thus, to some extent the unemployment is taken into account. Otherwise, we allow the analysis to determine whether a wedge, positive or negative, exists between the sectors.

\subsection{Variables and data}

In most countries, migration between agriculture and other sectors is not directly observed but must be inferred from observations on labor. To do this, it is assumed that without migration, labor in agriculture and non-agriculture would grow at the same rate as the total labor force. Deviations from this rate is attributed to migration. The more accurate labor and population data in many countries are obtained from the censuses which are ordinarily taken every ten years. For this reason we base our calculations of migration on data ten years apart. We let $L_{\tau}$ be total labor and define the off-farm migration over the decade as: 


$$
\bar{M}(t) \cdot\left(\frac{L_{T}(t)}{L_{T}(t-10)}\right) L_{a}(t-10)-L_{a}(t)
$$

Annualized migration rates were calculated as:

$$
m(t)=\frac{1}{10}\left(\frac{\tilde{M}(t)}{L_{\mathrm{p}}(t-10)}\right)
$$

The derivation in (3.1) assumes that the natural increase of the labor force, $n$, is the same for both sectors. This rate, is largely determined by the rate of population growth which may not be the same for the rural and urban sectors. Kuznets (1966) suggests that the rate for the rural population may be three times as high as for the urban one. There are different views on this issue, for instance in a survey of developing countries, Rogers (1982) calculated the rate of natural increase to be $2.25 \%$ for urban populations and $2.24 \%$ for rural populations in $\mathbf{1 9 6 0}$. However, the issue is far from settled. The assumption on the pertinent rates has an effect on the computed migration rates. In order to see the effect of this assumption on the results, we calculate migration rates under three additional assumptions.

The computed values are given in the Annex for the countries in the sample along with the underlying labor growth rates, and the ratio of non-agriculture labor to that of agricultural labor. The numbers on total and agricultural labor for 1950,1960,1970, and 1980 were taken from International Labor Organization (ILO) data maintained in the World Bank data base whereas the 1990 values were calculated from various ILO publications. 
The behavior of migration over time is summarized in Figures 3.1 and 3.2. Observations fall above the diagonal line when the migration rate increased between decades. The 1960 s brought a quick acceleration of migration rates and off-farm migration was a pervasive feature of most economies, whether developed or developing. By the 1980s, however, a greater variety of experiences emerged. In some countries, especially in Central America, off-farm migration accelerated to very high rates. Still, migration slowed or reversed in other countries.

The accumulative effect of decades of rapid off-farm migration has been an urbanization of the labor force. On average, the size of the labor force engaged in non-agriculture has grown relative to agricultural labor - it was about $1.2 \%$ per year in 1950 and grew tc $6.2 \%$ in 1980. Interestingly, the growth of this ratio was far from even; the coefficient of variation increased from about $2 \%$ in 1950 to $8 \%$ in 1980 . This increase in the spread is indicative of big differences in the pace of development across countries.

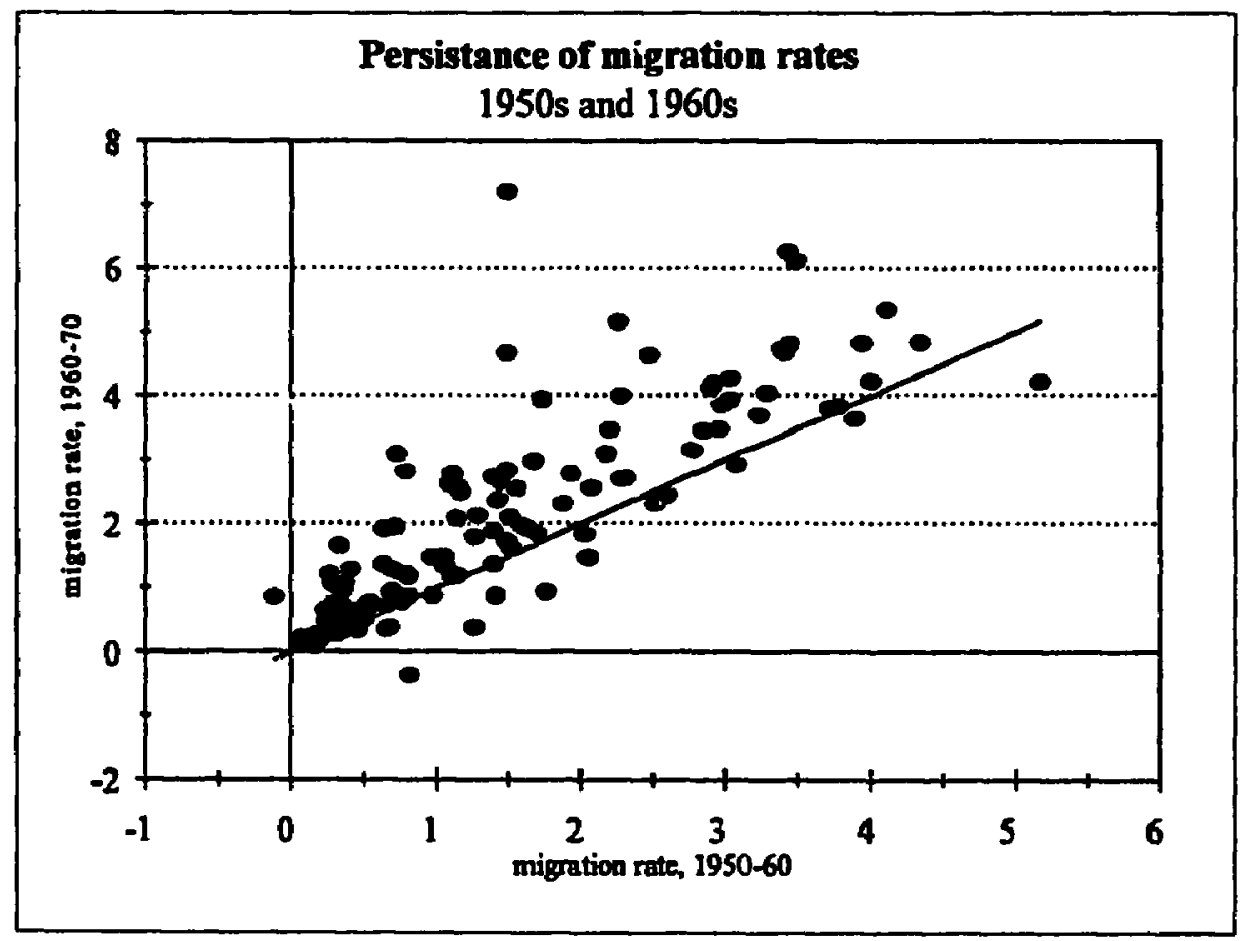

Figure 3.1: Migration rates accelerated in most countries during the 1960s. 


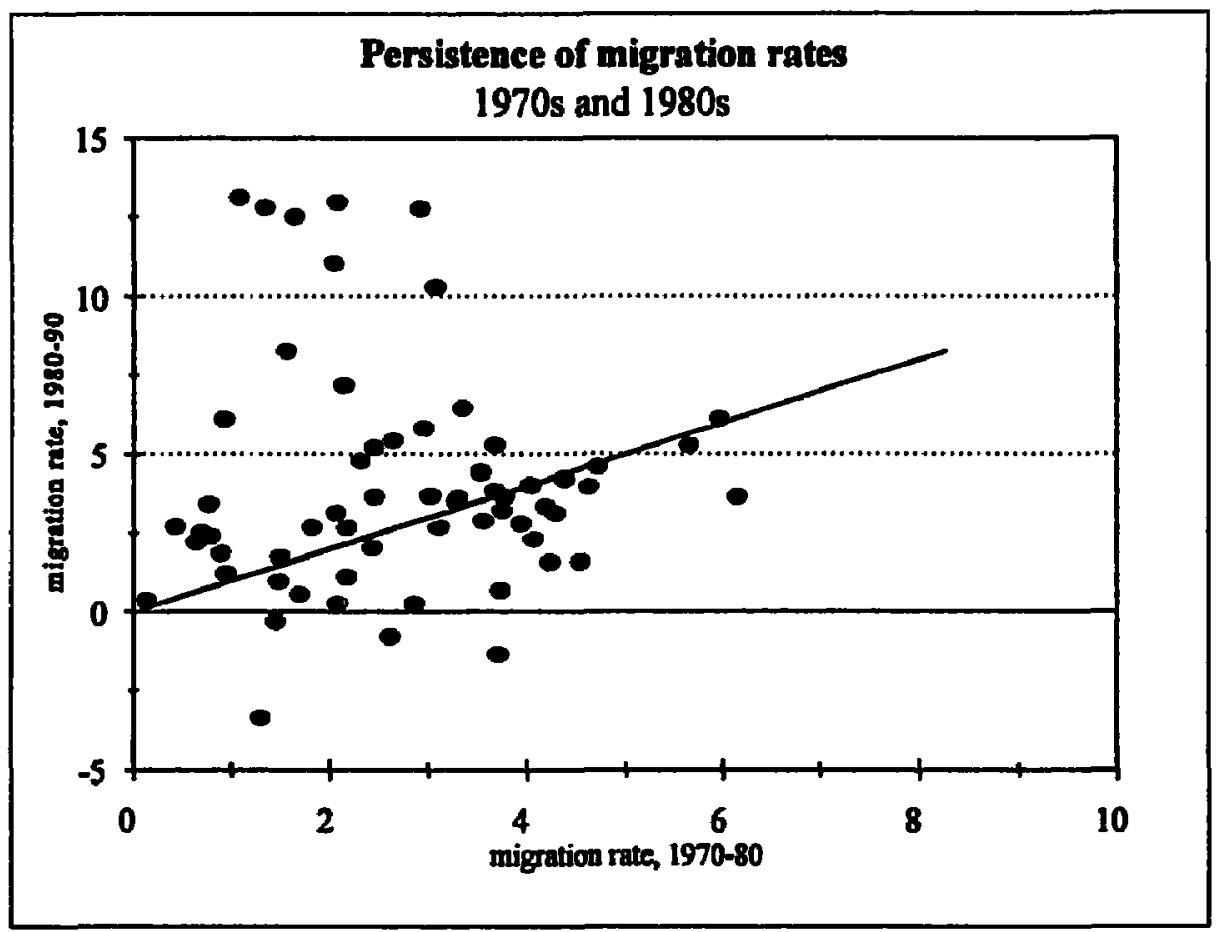

Figure 3.2: Migration rates slowed in some countries and accelerated in others during the 1980s.

The income differential is measured as the ratio of the average labor product in the two

sectors. This is the closest measure of consumption levels in the two sectors that is readily available.

We chose income rather than wages because there is no reason to assume that in choosing sectors, households preclude earning capital income at some stage of their life, or of the lives of their children. This reflects the underlying assumption that it is life-time expected utility, as measured empirically by per capita consumption, that matters. Of course, in the case of seasonal work or parttime farming, the wage rates might be more important, but the main changes in the composition of the labor force reflect structural changes with labor leaving agriculture altogether.

The data for agricuitural GDP and total GDP was taken from several sources. When available, the data was taken from the National Accounts data base at the World Bank. Missing observations were filled first from the various editions of the World Bank Tables, OECD National Accounts, and finally the UN National Accounts. Non-agricultural GDP was calculated as the 
difference. Agricultural and non-agricultural GDP were then divided by agricultural and nonagricultural labor numbers from ILO to provide average labor value products. The ratio of these products corresponds to 8 in equation (2.9). Figure 3.3 plots the ratio of average labor products for the four-decade sample against real per capita income. When the average value between the two sectors is equal, the ratio is equal to one and falls along the bold horizontal line near the bottom of the graph. The message from the graph is quite strong. In middle and high income countries, the ratio is almost equal to one and as the data show, this statement was as true in 1950 as it is today. This equality is achieved through off-farm migration and rising productivity in agriculture. As countries develop, labor remaining in agriculture, enhanced by greater stores of human and physical capital, grows more productive.

The cost of migration is a concept which is not easy to defiue for measurement and there are

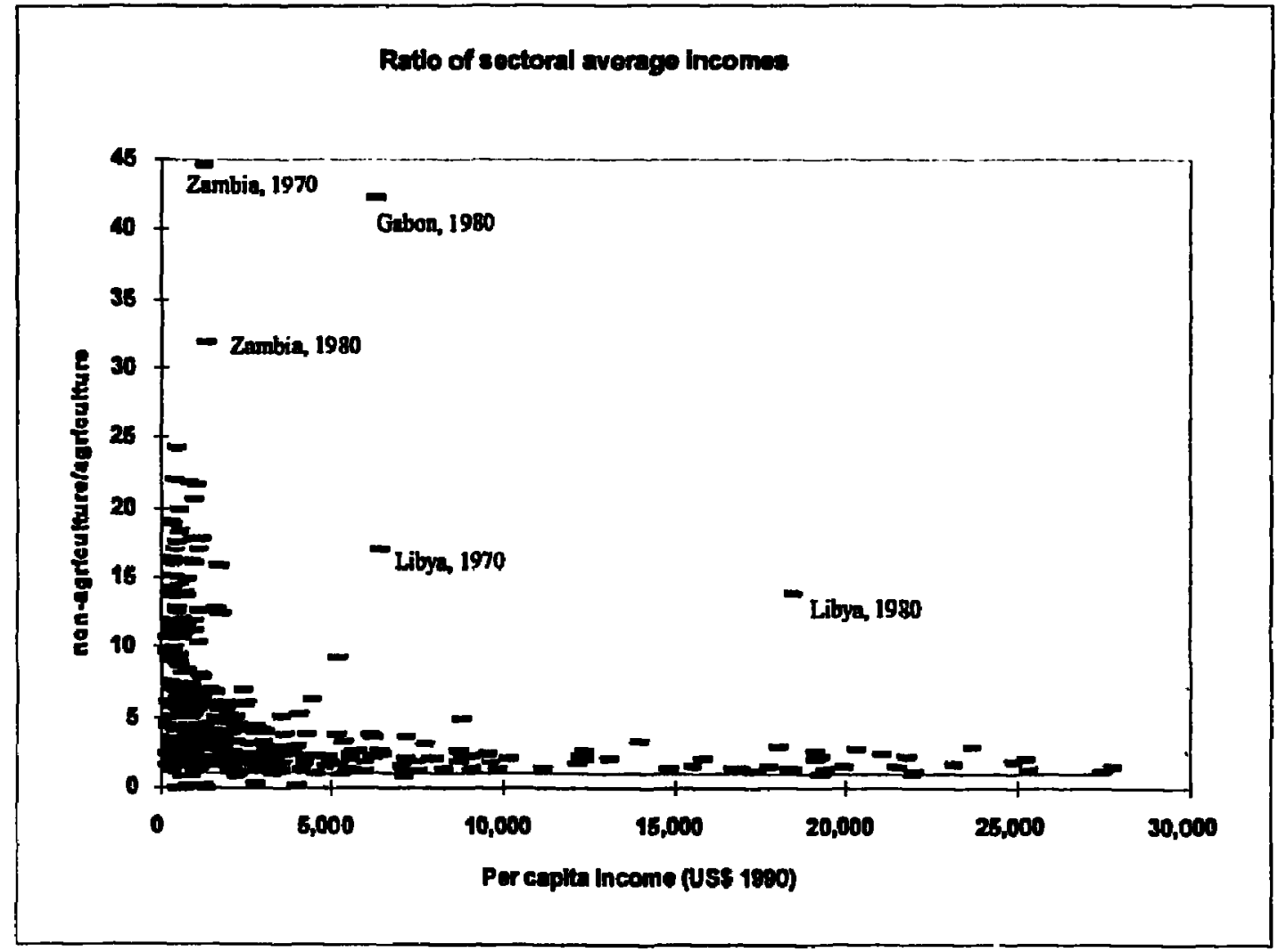

Figure 3.3: Average incomes between sectors converge as countries develop. 
no data that can be used to represent it. However, it is related to the availability and the performance of labor markets, markets for land titles, transportation, information networks and alike. All these are directly related to the level of development of the economy and therefore can be represented by a summary measure of per capita income. The per capita income is derived from the income data described above, combined with ILO population data.

Two additional characteristics of labor were included in the estimated model: the share of the labor force under the age of forty and the number of years of formal education. The age profile of labor is also taken from ILO data. The model suggests higher propensity to migrate for the young than for the old. This may show that countries with young labor force will have higher migration rates, other things equal, than countries with older labor force. The data show that for the sample as a whole there has been stability in the average age of the labor force over time. Yet there are big differences across countries with high concentration of young workers in most developing countries. For example, in Costa Rica in $1980,70 \%$ of all workers were under 40 years of age, compared to $51 \%$ in Japan. All things being equal, migration rates will increase as current cohorts of children mature, and should eventually decrease with slowing birth-rates. Still, looking across all countries, the average share of the labor pool under $\mathbf{4 0}$ remains fairly constant, despite large individual country differences.

In contrast, the world's labor is becoming, on average, increasingly better educated. The variable used to measure education is the average years of education for the country's adult (greater than 25 years of age) population and is taken from Barro and Lee (1993). The number of years of education has grown steadily from decade to decade. All other things equal, a better-educated labor force is expected to better avail itself of opportunities across sectors, and should prove more mobile. McMillan and Barkley (1992) suggested that economies characterized by free markets may not 
allocate resources, especially labor, efficiently if political suppression of either market information or resource mobility is present. They examined 32 African countries from 1972 to 1987 using a model similar to the model described in Section 2, and included in their state variables a measure of political rights constructed by Freedom House (1989). We have applied the same data to our broader set of countries. ${ }^{4}$ Two indices are included - one to measure civil liberties, another to measure political rights. The indices vary from 1 to 7.

The empirical model relies on data pooled across countries and time, and certainly there is a possibility of regional or time-dependent differences in the state variables that are not adequately represented in the model. Technology changes through time, philosophies of government evolve and regional customs exist. To account for such omissions, regional and decade dummies were also included in the model.

The sample used to estimate the model developed in section 2 included 242 observations from 96 countries. With the exception of the freedom measures, some data was available to calculate migration for four ten-year periods: 1950-60, 1960-70, 1970-80, and 1980-90. Data used in the study is contained in the Annex of Larson and Mundlak (1994). Table 3.1 provides average values for key regression variables by decade.

It is safe to assume that the data is subject to error. This is an inherent problem in all data collection. However, the coverage of countries and time period in this study justify a reminder of this shortcoming. This may be particularly pertinent for the sectoral labor data because the definition of what is considered to be agricultural labor varies between countries and over time. The effect of such data flaws can be considered as measurement error. It is a standard result that measurement

These data were provided to us by Avner Ahituv. 
Table 3.1: Average sample means for selected regression variables.

\begin{tabular}{crrrrrr}
\hline & $\begin{array}{r}\text { Number of } \\
\text { nhservations }\end{array}$ & $\begin{array}{r}\text { Migntion } \\
\text { Rate (\%) }\end{array}$ & $\begin{array}{r}\text { Ratio of } \\
\text { Avg. Income }\end{array}$ & $\begin{array}{r}\text { Ratio of } \\
\text { Sectoral Labor }\end{array}$ & $\begin{array}{r}\text { Education of } \\
\text { Labor Force }\end{array}$ & $\begin{array}{r}\text { Share of Work } \\
\text { under age } 40\end{array}$ \\
\hline $1950-60$ & 16 & 1.06 & 3.53 & 0.79 & 2.26 & .62 \\
$1960-70$ & 82 & 2.13 & 5.12 & 2.33 & 3.33 & .60 \\
$1970-80$ & 92 & 2.51 & 5.28 & 3.35 & 3.70 & .60 \\
$1980-90$ & 54 & 3.86 & 3.21 & 6.22 & 5.57 & .63 \\
$1950-90$ & 244 & 2.59 & 4.65 & 3.47 & 3.90 & .61 \\
\hline
\end{tabular}

errors bias the regression coefficients downward. The degree of the bias is determined by the ratio of the error variance to the total variance of the variable. In cross country analysis, the spread in the share of labor in the total labor force is very large and therefore it likely that the bias is contained within a reasonable bound. This should be kept in mind in the evaluation of the empirical results.

\subsection{Regression results}

The model was estimated from the pooled data described in Section 3 using a non-linear leastsquares procedure in SAS. We use the migration series obtained under various assumptions with respect to the differences in labor growth rates between the rural and urban populations. Various restricted versions of the model, in which some parameters were set to zero, were considered as well. We begin with the migration series obtained under the assumption of equal labor growth rates. The unconstrained results for the full model are presented in Table 4.1 and results from the constrainedmodel estimation are given in Table 4.2.

The results given in Table 4.1 suggest that the rate of off-farm migration increased, on average, by roughly 0.3 percent when the income differential (ratio of average products between agriculture and non-agriculture) increases by 1 percent. The estimate and its level of significance are robust under the alternative specifications given in Table 4.2. The estimates are contained by a 
relatively narrow band $(0.29$ to

0.56). These estimates are

comparable to those reported by

Mundlak (1979) for a similar model

estimated for 70 countries for the

period 1960-70. The latter study

did not include the political

variables and regional dummies.

Nevertheless, the results are quite

similar as the income differential

coefficient varied in the range 0.22
Table 4.1:Regression results for full model

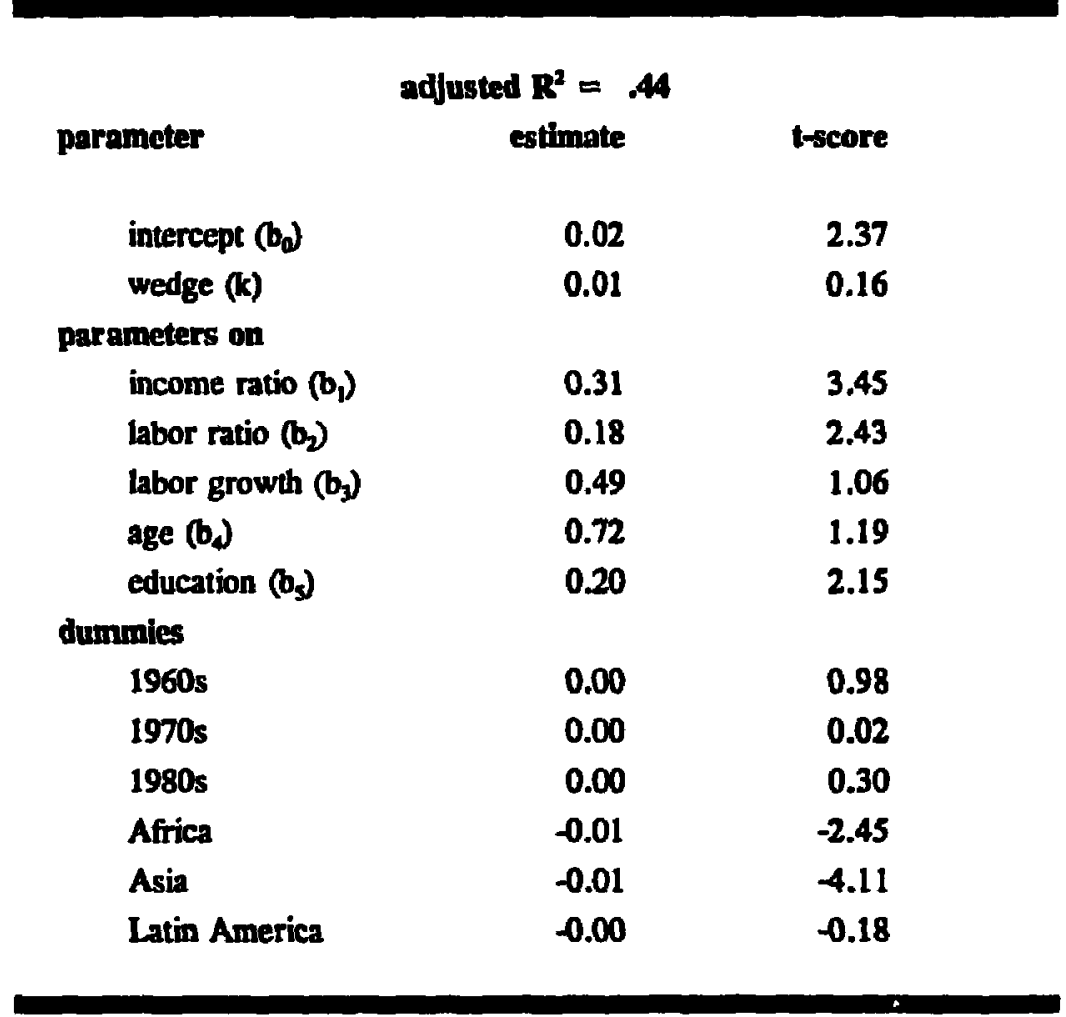

to 0.52 . This similarity suggests

that the migration relation used in these studies is fairly stable.

The intercept is 0.02 , which amounts to a migration rate of 2 percent. The intercept falls well within the spread of the dependent variable.

The specification of (2.7) makes it is possible to derive an empirical estimate of the income differential at which migration between sectors stops. As discussed above, there are plausible explanations why an income wedge might exist between the sectors. However, it is striking that the estimated wedge between agriculture and non-agriculture, defined as $k$ in (2.9), is negligible and not significantly different from zero. This result is robust and occurs under all versions of the model. The economic meaning of this result is that migration stops at the point where average labor 
Table 4.2:Regression results for constrained versions of the model.

\begin{tabular}{|c|c|c|c|c|c|c|}
\hline \multirow[b]{2}{*}{ parameter } & \multicolumn{2}{|c|}{$\begin{array}{c}\text { model } 1 \\
\text { adfusted } \mathrm{R}^{2}=37\end{array}$} & \multicolumn{2}{|c|}{$\begin{array}{c}\text { modal } 2 \\
\text { adjusted } R^{2}=38\end{array}$} & \multicolumn{2}{|c|}{$\begin{array}{c}\text { model } 3 \\
\text { adfusted } \mathrm{R}^{2}=.44\end{array}$} \\
\hline & estimate & t-acore & cothenate & tescore & estimate & t-acore \\
\hline intercept $\left(b_{0}\right)$ & 0.01 & 2.68 & 0.02 & 2.30 & 0.02 & 2.82 \\
\hline wedge (k) & 0.02 & 0.22 & 0.02 & 0.24 & 0.01 & 0.12 \\
\hline \multicolumn{7}{|l|}{ parnmeters on } \\
\hline income mato $\left(b_{1}\right)$ & 0.57 & 5.91 & 0.56 & 5.16 & 0.29 & 3.40 \\
\hline labor matio $\left(b_{2}\right)$ & 0.38 & 5.47 & 0.38 & 4.81 & 0.16 & 2.36 \\
\hline labor growth (b) & 0.39 & 0.81 & 0.43 & 0.93 & 0.43 & 1.00 \\
\hline age $\left(b_{4}\right)$ & 0.93 & 1.72 & 1.04 & 1.76 & 0.62 & 1.22 \\
\hline $\begin{array}{l}\text { education (bs) } \\
\text { dummy variables }\end{array}$ & 0.32 & 2.53 & 0.32 & 2.43 & 0.18 & 2.19 \\
\hline 19603 & - & - & 0.00 & 0.63 & - & - \\
\hline 1970 s & - & - & -0.00 & -0.74 & - & - \\
\hline $1980 \mathrm{~s}$ & - & - & -0.00 & -0.46 & - & - \\
\hline Africa & - & - & - & - & -0.00 & -2.43 \\
\hline Asia & - & - & - & - & -0.00 & -4.29 \\
\hline Latin America & - & - & - & - & -0.00 & 0.19 \\
\hline
\end{tabular}

productivity is equal in both sectors. The emphasis is on average rather than marginal productivity. ${ }^{5}$ Average labor productivity reflects eventual capital (physical and human) income in addition to labor income. Since total income determines consumption, the results are consistent with the assumption that migration is affected by consumption differences between the two sectors - that is, differences in the value of the indirect utility functions as developed in Section 2. In conclusion, the results provide strong evidence that migration continues until average labor product values are equal between sectors. This result may be peculiar to the labor choice between agriculture and non-agriculture where the

'When the production function is Cobb-Douglas equality of average productivity is the same as equality of marginal productivities provided that the production elasticities are the same for all observations in the sample. There is a good reason to believe that this assumption has no empirical validity. 
choice of occupation is strongly associated with the change of residence. This aspect of the choice may differ from those choices of occupation within the non-agricultural sector where a career change based on wages involve no change in other pertinent attributes.

The estimated parameter for the labor composition (ratio of non-agricultural labor to agricultural labor) depends on the model and the values in Tables 4.1 and 4.2 ranged from 0.15 to 0.38. The estimated parameters on the labor growth rate varied from 0.39 to 0.49 and were not significantly different from one. Of course, this result does not imply equality of income across sectors. What it says is that if we take the income as a measure of the distance between the distributions of the two sectors, migration will atop at the point of equality. Also note that migration has not stopped yet in most countries, including the affluent countries with low labor force in agriculture. For instance, the average annual migration rate for the United States for the period 1980 to 1990 was 2.0 percent and that of the United Kingdom for the same period was 2.4 percent.

The age of the labor force was positive in all versions of the model implying that migration rates are higher in countries with younger population. However, the age variables is correlated with the regional effects. Once regional dummies were introduced for Asia and Africa where populations are relatively young, the associated parameter was no longer significant. The effect of education is positive, important and significant. This result is consistent with the hypothesis that education improves labor mobility.

Turning to the dummies, interestingly, no decade-effect on the migration rate was found in the estimation. This is another indication that the relation is stable over time. This is encouraging since it suggests that the data can be pooled readily across time.

A negative regional effect does show up for Africa and Asia, implying migration rates are lower when all other factors are equal. Empirically, the estimated regional effect is similar for the 
two regions. One possible explanation, shared by countries in both regions, has to do with laws affecting land ownership. In may parts of Africa ar.J Asia deeded land is rare and ownership is determined by use. Therefore, migrating families may bear the additional cost of foregoing claims on land without compensation.

Table 4.3 reports results for three different migration series, based on the assumption that fertility rates in the rural areas are higher than in the urban areas. The first column of Table 4.3 reports estimates based on the assumption that growth rates are twice as high in rural areas as in urban areas. The assumption generates a much larger spread in the dependent variable. The same is also true of the other methods of calculating migration. Column 2 of Table 4.3 reports results based on the assumption that rural growth rates are 1.5 times as large as urban rates. Column 3 reports results based on the assumption that birth rates are a function of relative share of labor in agriculture. ${ }^{6}$ Under all three of the alternative specification for migration, the main conclusions from the earlier section remain unchanged. Migration remains significantly responsive to income differentials and no significant wedge is apparent between average income in agriculture and non-agriculture. In addition, the parameters associated with the decade dummies suggested no problem with pooling the data over time. As earlier, there were significant regional effects in Asia and Africa.

\footnotetext{
In this case the growth rate for agriculture is to first express the overall growth rate for labor $\left(n_{l}\right)$ as a weighted average of the growth rates for agriculture $\left(n_{a}\right)$ and non-agriculture $\left(n_{n}\right)$ so that $n_{f}=s_{a} n_{a} \cdot\left(1-s_{a}\right) s_{n}$. With the additional assumption that the ratio of growth-rates is constant $\left(n_{n}-\lambda n_{a}\right)$, the growth rate for agricultural labor can be expressed as the following non-linear relationship between the growth rate for total labor and agriculture's share of labor: $n_{a}=n_{l} /\left(s_{a}+\lambda-\lambda s_{a}\right)$. Results reported in Table 4.3 (under M3) were based on the assumption that $\lambda=0.75$.
} 
Tablo 4.3:Regression results under alternative definitions of migration.

\begin{tabular}{|c|c|c|c|c|c|c|}
\hline \multirow[b]{2}{*}{ parnmeter } & \multicolumn{2}{|c|}{$\begin{array}{c}M 1(2: 1) \\
\text { adjurted } R^{2}=.86\end{array}$} & \multicolumn{2}{|c|}{$\begin{array}{r}M 2(1.581) \\
\text { adfunted } R^{2}=.67\end{array}$} & \multicolumn{2}{|c|}{$\begin{array}{l}\text { MB: (nllding menle) } \\
\text { adjunted } R^{2}=.65\end{array}$} \\
\hline & eatinate & Iticore & extimate & 1-neore & extimate & ineor \\
\hline intercept $\left(b_{0}\right)$ & 0.05 & 6.55 & 0.04 & 4.15 & 0.06 & 3.19 \\
\hline wodge (k) & -0.02 & -0.13 & -0.00 & -0.01 & 0.02 & 0.23 \\
\hline \multicolumn{7}{|l|}{ parametern on } \\
\hline Income natio $\left(b_{1}\right)$ & 0.12 & 3.20 & 0.18 & 3.25 & 0.16 & 2.81 \\
\hline labor ndto $\left(b_{2}\right)$ & 0.23 & 7.60 & 0.18 & 4.10 & 0.04 & 0.88 \\
\hline labor growth $\left(b_{3}\right)$ & 0.87 & 5.17 & 0.78 & 2.95 & 0.89 & 2.55 \\
\hline age $\left(b_{4}\right)$ & 0.08 & 0.40 & 0.33 & 0.96 & 1.42 & 2.74 \\
\hline education (by) & 0.10 & 3.00 & 0.13 & 2.54 & 0.09 & 1.75 \\
\hline \multicolumn{7}{|l|}{ dumany vartablea } \\
\hline $1960 \mathrm{~s}$ & 0.00 & 0.60 & 0.00 & 0.94 & 0.00 & 1.58 \\
\hline $1970 \mathrm{~s}$ & -0.00 & -0.17 & 0.00 & 0.08 & 0.00 & 0.84 \\
\hline $1980 \mathrm{~s}$ & -0.00 & -0.72 & 0.00 & 0.65 & 0.00 & 0.76 \\
\hline Africa & .0 .03 & -3.88 & -0.02 & -3.26 & -0.03 & -3.75 \\
\hline Asin & -0.03 & -7.74 & -0.02 & -5.72 & -0.02 & -3.72 \\
\hline Latin America & -0.00 & -1.23 & -0.00 & 0.60 & 0.00 & 0.12 \\
\hline
\end{tabular}

The introduction of per capita income as a measure of development (Table 4.4) did not change the results. The variable is correlated with most of the explanatory variables and its effect may be reflected in the coefficients of those variables.

The results from including freedom measures (Table 4.5) were equivocal. ${ }^{7}$ The estimated values were insignificant and were of differing signs (positive for civil liberties and negative for political liberties). Also, unlike results given by McMillan and Barkley, including or excluding the

Because the political and civil rights measures were only available for 1965-1990, observations on the freedom measures were used for the mid-point of migration period, for example the political rights measure from 1965 was used to explain migration from 1960 to 1970 , etc. Observations for 1950-60 migration were dropped for this portion of the analysis. 
Table 4.4: Effects of development variable on parameter estimates.

\begin{tabular}{|c|c|c|c|c|}
\hline \multirow[b]{2}{*}{ parameter } & \multicolumn{2}{|c|}{ adjusted $\mathrm{R}^{2}=.44$} & \multicolumn{2}{|c|}{ adfurted $R^{2}=.44$} \\
\hline & stmate & t-score & exthanate & incore \\
\hline intercept $\left(b_{0}\right)$ & 0.02 & 2.37 & 0.01 & 1.23 \\
\hline wedge (k) & 0.01 & 0.16 & 0.01 & 0.98 \\
\hline \multicolumn{5}{|l|}{ parameters on } \\
\hline income mato $\left(b_{1}\right)$ & 0.31 & 3.45 & 0.29 & 3.08 \\
\hline Labor ratio (by) & 0.18 & 2.43 & 0.11 & 1.09 \\
\hline labor growth (b) & 0.49 & 1.06 & 0.53 & 1.14 \\
\hline age $\left(b_{4}\right)$ & 0.72 & 1.19 & 0.83 & 1.33 \\
\hline education (by) & 0.20 & 2.15 & 0.18 & 1.93 \\
\hline development $\left(b_{b}\right)$ & - & - & 0.09 & 0.89 \\
\hline \multicolumn{5}{|l|}{ dummy variables } \\
\hline $1960 \mathrm{~s}$ & 0.00 & 0.98 & 0.00 & 1.09 \\
\hline 1970s & 0.00 & 0.02 & 0.00 & 0.17 \\
\hline 1980s & 0.00 & 0.30 & 0.00 & 0.29 \\
\hline Africa & -0.01 & -2.45 & -0.01 & -2.36 \\
\hline Asin & -0.01 & -4.11 & -0.01 & -3.59 \\
\hline Latin America & -0.00 & -0.18 & -0.00 & -0.12 \\
\hline
\end{tabular}

variables had limited effect on the estimated coefficient of the income differential.

\subsection{Conclusions}

The underlying postulate in the study of migration is that individuals compare the benefits of migration against costs. Because individuals differ in the attributes that determine their income in various occupations as well as their cost of migration, under any given market condition some individuals find it to their benefit to migrate while others do not. When the income differences between the alternative occupations increase, more individuals migrate. It is this heterogeneity among individuals that relates the size of the income difference to the pace of migration.

This general assertion is supported empirically in this study of off-farm migration where the rate of migration is found to be positively related to the income differential between agriculture and 
Table 4.5: Effects of freedom variable on parameter estimates.

\begin{tabular}{|c|c|c|c|c|}
\hline \multirow[b]{2}{*}{ parameter } & \multicolumn{2}{|c|}{ ad!usted $\mathrm{R}^{2}=.44$} & \multicolumn{2}{|c|}{ ndjusted $\mathbf{R}^{2}=.44$} \\
\hline & estlmate & t-score & estimnte & i-score \\
\hline intercept $\left(b_{0}\right)$ & 0.02 & 2.71 & 0.02 & 2.24 \\
\hline wedge (k) & 0.01 & 0.13 & 0.01 & 0.07 \\
\hline \multicolumn{5}{|l|}{ parameters on } \\
\hline income ratio $\left(b_{1}\right)$ & 0.28 & 3.54 & 0.21 & 2.59 \\
\hline labor ratio $\left(b_{2}\right)$ & 0.16 & 2.46 & 0.10 & 1.41 \\
\hline labor growth $\left(b_{1}\right)$ & 0.50 & 1.19 & 0.36 & 0.81 \\
\hline age $\left(b_{4}\right)$ & 0.61 & 1.12 & 0.19 & 0.31 \\
\hline education (b, & 0.18 & 2.26 & 0.26 & 3.12 \\
\hline civil liberties & - & - & 0.24 & 1.48 \\
\hline political liberties & - & - & -0.08 & -0.55 \\
\hline \multicolumn{5}{|l|}{ dummy variables } \\
\hline $1970 \mathrm{~s}$ & -0.00 & -1.22 & 0.00 & 0.17 \\
\hline 19805 & -0.00 & -0.53 & 0.00 & 0.29 \\
\hline Africa & -0.01 & -2.43 & -0.01 & -2.36 \\
\hline Asia & -0.01 & -4.17 & -0.01 & -3.59 \\
\hline Latin America & 0.00 & -0.32 & -0.00 & -0.12 \\
\hline
\end{tabular}

non-agriculture. As such, the labor supply of agriculture to non-agriculture is upward sloping.

Factors that increase income in agriculture relative to non-agriculture slow down the labor supply to non-agriculture. Contrary to various arguments, the results do not suggest that a permanent wedge exists between agricultural and non-agricultural income implying that migration stops when the income is equal across sectors. The measure of income used in this study is average labor productivity which includes wage income and returns to human and physical capital because the choice of sectors affects not only wages but other opportunities as well. For the time frame of this study, 1950-1990, the results are stable and insensitive to sub-periods used for the analysis.

As more people leave agriculture, the economic base of non-agriculture increases (the ratio of labor in non-agriculture to that in agriculture) and that has a positive effect on migration rates. This 
shift in the composition of the labor force affects the dynamics of labor allocation. Also, as labor leaves agriculture, labor productivity in agriculture increases, the income differential decreases and the migration rate declines. As such, off-farm migration simultaneously leads to an increase of income in the rural sector and to the development of non-agriculture. However, due to the heterogeneity of individuals who base their decision to migrate on lifetime utility and the resulting dependence of the pace of migration on differences in income, this process takes a long time to complete. 


\section{References}

Bellante, D. 1979. "The North-South Differential and the Migration of Heterogeneous Labor." American Economic Review 69: 166-75.

Barro, Robert and Jong-Wha Lee. 1993. "International Comparisons of Educational Attainment." Washington, D.C.: World Bank.

Coeymans, J. E. and Y. Mundlak. 1993. Sectoral Growth in Chile: 1962-82, Research Report 95. Washington, D.C.: International Food Policy Research Institute.

Freedom House. 1989. Freedom in the World. Westport, Conn.: Greenwood Press.

Fei, J. C. H. and G. Ranis. 1964. Development of the Labor Surplus Economy: Theory and Policy. Homewood, Ill.: Richard D. Irwin.

Fishlow, A. 1972. "Brazilian Size Distribution of Income." American Economic Review 62(2): 391-402.

Greenwood, M. 1975. "Research on Internal Migration in the United States: A Survey." Journal of Economic Literature, 13, 397-433.

Hicks, J. 1932. The Theory of Wages. London: Macmillan.

Jorgenson, D. 1961. "The Development of a Dual Economy." Economic Journal 71 (June).

Kuznets, S. 1966. Modern Economic Growth. New Haven, Conn.: Yale University Press.

Lewis, W. A. 1954. "Economic Development with Unlimited Supplies of Labour." Manchester School of Economic and Social Studies 22 (May): 139-91.

McMillan, John, and Andrew Barkley. 1992 "Political Freedom and the Response to Economic Incentives: Labor Migration in Africa, 1972-1987." Institute for Policy Reform Working Paper Series. Washington D.C.: Institute for Policy Reform.

Molho, Ian. 1986. "Theories of Migration: A Review." Scottish Journal of Political Economy, 33 (November): 396-419.

Mundlak, Y. 1979. Intersectoral Factor Mobility and Agricultural Growth. Research Report 6. Washington, D.C.: International Food Policy Research Institute. 
Mundlak, Y., D. Cavallo, and Domenech, R. 1989. Agriculture and Economic Growth in Argentina, 1913-84. Research Report 76. Washington, D.C.: International Food Policy Research Institute.

Palson, A. 1994, Insurance Motives for Migration: Evidence from Thailand. The University of Chicago, Ph.D Thesis.

Ravenstein, E. 1889. "The Laws of Migration", Journal of the Statistical Society, 52: 214301.

Rogers, A. and J. G. Williamson. 1982. "Migration, Urbanization, and Third World Development: An Overview." Economic Development and Cultural Change (April): 463-82.

Squire, L. 1981. Employment Policy in Developing Countries. Oxford: Oxford University Press.

Smith, Adam. 1937 (1776.) The Wealth of Nations. Edited by Edwin Cannan. New York: Modern Library, Inc.

Sjaastad, L. 1962. "The Costs and Returns of Human Migration", Journal of Political Economy, 70: 80-93.

Stark, O. 1991. The Migration of Labor. Oxford: Basil Blackwell.

Tcha, M. 1992. Altruism and Migration - Evidence from Korea and the U.S., The University of Chicago, Ph.D Thesis.

Todaro, M. P. 1969. "A Model of Labor Migration and Urban Unemployment in Less Developed Countries." American Economic review 59, 1 (March): 138-48.

Williamson, J. G. 1990. Coping with City Growth During the British Industrial Revolution. Cambridge: Cambridge University Press.

Yap, L. 1977. "The Attraction of Cities: A Review of the Migration Literature." Journal of Development Studies 4: 239-64. 
Annex 1: Ratio of non-agriculture to agriculture average labor products

\begin{tabular}{|c|c|c|c|c|c|}
\hline & 1950 & 1960 & 1970 & 1980 & 1990 \\
\hline Afghanistan & - & - & - & $\cdot$ & - \\
\hline Albania & - & - & - & 3.30 & 3.11 \\
\hline Algeria & 7.27 & 10.44 & 8.01 & 5.10 & . \\
\hline Angola & . & - & . & 12.64 & . \\
\hline Argentina & 2.07 & 1.46 & 1.77 & 2.21 & . \\
\hline Australia & 0.45 & 0.85 & 1.43 & 1.32 & 1.64 \\
\hline Austria & 2.64 & 2.52 & 2.36 & 2.12 & 2.55 \\
\hline Bangladesh & . & 4.56 & 3.65 & 3.01 & . \\
\hline Barbados & . & 1.50 & 2.07 & 1.10 & - \\
\hline Belgium & . & 1.11 & 1.36 & 1.34 & 1.34 \\
\hline Benin & - & 6.62 & 7.42 & 4.29 & . \\
\hline Bhutan & - & - & - & 9.64 & . \\
\hline Bolivia & - & 3.28 & 4.39 & 3.86 & 0.03 \\
\hline Botswana & - & 9.27 & 11.96 & 15.88 & . \\
\hline Brazil & 2.77 & 5.06 & 7.04 & 4.10 & 3.03 \\
\hline Bulgaria & . & 2.78 & 1.83 & 1.31 & - \\
\hline Burkina Faso & - & 9.26 & 11.44 & 11.08 & - \\
\hline Burma & 3.33 & 4.42 & 2.36 & 1.29 & 1.56 \\
\hline Burundi & . & - & 7.60 & 9.41 & - \\
\hline Cameroon & . & - & 11.02 & 6.01 & . \\
\hline Canada & 1.56 & 2.02 & 2.12 & 1.41 & . \\
\hline Cape Verde & . & . & - & 6.77 & 2.12 \\
\hline Central African Republic & . & 13.92 & 9.70 & 4.34 & 4.33 \\
\hline Chad & . & 18.82 & 11.99 & 4.35 & . \\
\hline Chile & 2.64 & 4.18 & 4.14 & 2.53 & 2.22 \\
\hline China & - & 17.13 & 6.98 & 6.59 & - \\
\hline Colombia & 2.14 & 1.95 & 1.93 & 2.17 & 0.07 \\
\hline Comoros & $\cdot$ & $\cdot$ & $\cdot$ & 9.45 & - \\
\hline Congo & 3.15 & 6.71 & 8.52 & 12.57 & . \\
\hline Costa Rica & - & 2.98 & 2.55 & 2.05 & 1.81 \\
\hline Cuba & - & . & . & - & - \\
\hline Cyprus & 2.98 & 3.51 & 3.10 & 3.32 & 2.11 \\
\hline Czechoslovakia & 3.14 & 1.81 & 1.60 & 2.12 & $\cdot$ \\
\hline Denmark & 1.34 & 1.34 & 2.13 & 1.57 & 1.43 \\
\hline Dominican Republic & 7.12 & 5.74 & 4.00 & 3.34 & . \\
\hline Ecuador & 3.57 & 4.11 & 3.25 & 4.55 & 2.88 \\
\hline Egypt & - & 3.57 & 3.20 & 3.98 & 3.22 \\
\hline El Salvador & 2.89 & 3.44 & 3.20 & 1.97 & 0.92 \\
\hline Equatorial Guinea & . & - & - & - & - \\
\hline Ethiopia & 5.40 & 4.34 & 5.18 & 4.65 & - \\
\hline Fiji & - & . & 3.17 & 3.37 & . \\
\hline Finland & 1.65 & 1.91 & 1.96 & 1.44 & 1.57 \\
\hline France & 2.53 & 2.72 & 2.28 & 2.12 & 1.61 \\
\hline Gabon & . & 12.05 & 17.18 & 42.40 & . \\
\hline Gambia & . & 16.39 & 16.24 & 13.98 & . \\
\hline Germany, East (former) & $\cdot$ & - & . & . & . \\
\hline
\end{tabular}


Annex 1 (cont'd): Ratio of non-agriculture to agriculture average labor products

\begin{tabular}{|c|c|c|c|c|c|}
\hline & 1950 & 1960 & 1970 & 1980 & 1990 \\
\hline Germany, West (former) & 2.11 & 2.66 & 2.43 & 2.89 & . \\
\hline Ghana & . & 2.53 & 1.61 & 0.92 & . \\
\hline Greece & 2.75 & 4.30 & 3.91 & 2.39 & . \\
\hline Guadeloupe & . & . & . & . & . \\
\hline Guatemala & 4.39 & 4.65 & 4.58 & 3.53 & 2.74 \\
\hline Guinea & . & 3.73 & 5.06 & 7.24 & . \\
\hline Guinea-Bissau & . & . & 5.88 & 5.86 & . \\
\hline Guyana & 1.48 & 1.99 & 2.32 & 1.40 & . \\
\hline Haiti & 2.12 & . & . & . & . \\
\hline Honduras & 2.66 & 4.64 & 4.46 & 5.70 & 2.17 \\
\hline Hungary & 3.22 & 2.06 & 1.50 & 1.08 & 1.69 \\
\hline Iceland & . & 3.97 & 3.22 & 1.02 & . \\
\hline India & 3.47 & 3.79 & 3.57 & 4.41 & . \\
\hline Indonesia & 3.00 & 2.54 & 2.41 & 4.24 & 4.39 \\
\hline Iran & . & 1.22 & 3.50 & 2.68 & . \\
\hline Iraq & . & . & 4.28 & . & . \\
\hline Ireland & 1.47 & 1.73 & 2.13 & 1.93 & 1.49 \\
\hline Israel & & 1.71 & 1.93 & 1.47 & . \\
\hline Italy & 1.78 & 2.57 & 2.73 & 2.24 & 2.59 \\
\hline Ivory Coast & 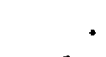 & 6.03 & 6.95 & 5.37 & . \\
\hline Jamaica & 2.65 & 6.15 & 6.99 & 5.08 & 5.67 \\
\hline Japan & 2.88 & 3.27 & 3.75 & 3.28 & 2.98 \\
\hline Jordan & . & 4.37 & 2.44 & 1.65 & . \\
\hline Kampuchea & . & . & . & . & . \\
\hline Kenya & 10.60 & 12.67 & 12.94 & 11.08 & \\
\hline Korea, North & . & . & . & . & . \\
\hline Korea, South & 2.95 & 2.73 & 2.75 & 3.26 & 2.18 \\
\hline Laos & . & . & . & . & . \\
\hline Lebanon & . & 4.80 & 2.45 & . & . \\
\hline Lesotho & . & 6.26 & 19.04 & 24.41 & . \\
\hline Liberia & . & . & 12.00 & 6.08 & . \\
\hline Libya & . & . & 17.11 & 13.93 & . \\
\hline Luxembourg & 2.32 & 2.11 & 2.18 & 2.22 & 1.93 \\
\hline Madagascar & . & 10.80 & 18.38 & 11.63 & . \\
\hline Malawi & . & 15.16 & 13.77 & 9.99 & . \\
\hline Malaysia & . & 3.45 & 2.92 & 2.54 & . \\
\hline Mali & 8.02 & 10.78 & 5.19 & 4.21 & . \\
\hline Malta & . & 1.66 & 1.13 & 1.57 & . \\
\hline Martinique & . & . & . & . & . \\
\hline Mauritania & . & 17.61 & 14.68 & 5.67 & . \\
\hline Mauritius & . & 4.59 & 3.32 & 3.30 & 1.90 \\
\hline Mexico & 6.04 & 6.82 & 5.99 & 6.42 & 3.26 \\
\hline Mongolia & . & & & - & \\
\hline Morocco & . & 6.27 & 5.46 & 3.71 & 0.17 \\
\hline Mozambique & . & . & . & 6.12 & $\cdot$ \\
\hline Namibia & . & - & . & 5.92 & - \\
\hline
\end{tabular}


Annex 1 (cont'd): Ratio of non-agriculture to agriculture average tabor products

\begin{tabular}{|c|c|c|c|c|c|}
\hline & 1950 & 1960 & 1970 & 1980 & 1990 \\
\hline Nepal & . & . & 7.28 & 9.61 & . \\
\hline Netherlands & 1.30 & 1.02 & . & . & 1.06 \\
\hline Nicaragua & . & 5.23 & 3.14 & 2.89 & - \\
\hline Niger & . & 8.33 & 8.90 & 13.79 & . \\
\hline Nigeria & 1.57 & 1.91 & 3.96 & 5.93 & . \\
\hline Norway & 2.02 & 2.49 & 2.26 & 2.28 & 2.05 \\
\hline Pakistan & 1.60 & 2.00 & 2.85 & 3.33 & 3.28 \\
\hline Panama & 4.77 & 5.04 & 4.31 & 4.25 & 2.40 \\
\hline Papua New Guinea & . & 0.05 & 0.23 & 0.26 & - \\
\hline Paraguay & 1.74 & 2.27 & 2.35 & 2.35 & 0.03 \\
\hline Peru & 2.18 & 4.08 & 3.88 & 5.90 & . \\
\hline Philippines & 3.03 & 4.57 & 2.89 & 3.20 & 2.51 \\
\hline Poland & . & 2.64 & 3.05 & 2.46 & 4.19 \\
\hline Portugal & 2.50 & 2.25 & 2.43 & 3.05 & . \\
\hline Reunion & . & - & . & - & - \\
\hline Romania & . & - & . & . & 1.82 \\
\hline Rwanda & . & 4.63 & 9.23 & 15.21 & 14.27 \\
\hline Senegal & . & 16.19 & 15.05 & 17.87 & . \\
\hline Sierra Leone & . & . & 9.04 & 5.24 & - \\
\hline Singapore & . & 2.19 & 1.50 & 1.24 & . \\
\hline Somalia & . & 2.66 & 3.45 & 1.71 & . \\
\hline South Africa & 2.52 & 3.57 & 6.14 & 3.89 & 2.24 \\
\hline Soviet Union (former) & . & - & . & - & - \\
\hline Spain & . & 2.34 & 2.99 & 2.72 & 2.69 \\
\hline Sri Lanka & 2.17 & 2.83 & 3.29 & 3.29 & 2.26 \\
\hline Sudan & . & 4.61 & . & 5.48 & . \\
\hline Suriname & . & 3.79 & 4.24 & 3.00 & 0.26 \\
\hline Swaziland & . & 19.94 & 11.38 & 12.45 & . \\
\hline Sweden & 2.29 & 2.11 & 2.16 & 1.73 & 1.28 \\
\hline Switzerland & . & - & . & . & - \\
\hline TMP & . & - & - & . & - \\
\hline Tanzania & 9.63 & 11.12 & 16.09 & 22.01 & . \\
\hline Thailand & 4.48 & 8.97 & 11.26 & 8.05 & 12.87 \\
\hline Togo & . & 3.20 & 6.47 & 7.13 & . \\
\hline Trinidad & . & 2.20 & 4.44 & 4.90 & . \\
\hline Tunisia & . & . & 3.55 & 3.27 & 1.63 \\
\hline Turkey & 5.81 & 6.23 & 6.61 & 5.16 & 4.02 \\
\hline Uganda & . & 12.22 & 48.83 & 2.54 & . \\
\hline United Kingdom & 0.98 & 1.19 & 1.17 & 1.43 & 1.26 \\
\hline United States & 1.76 & 1.74 & 1.58 & 1.34 & 1.32 \\
\hline Uruguay & 1.77 & 0.89 & 1.17 & 1.19 & 0.29 \\
\hline Venezuela & . & 9.34 & 5.29 & 3.75 & 2.35 \\
\hline Viet Nam & - & - & . & - & - \\
\hline Yemen, PDR & . & . & . & - & - \\
\hline Yugoslavia & 6.86 & 6.05 & 5.17 & 3.88 & - \\
\hline Zaire & . & 16.12 & 21.87 & 7.39 & - \\
\hline Zambia & . & 53.50 & 44.64 & 31.89 & . \\
\hline Zimbabwe & . & 21.73 & 20.62 & 17.76 & . \\
\hline
\end{tabular}


Annex 2: Ratio of non-agricultural labor force to agricultural labor force

\begin{tabular}{|c|c|c|c|c|c|}
\hline & 1950 & 1960 & 1970 & 1980 & 1990 \\
\hline Afghanistan & 0.32 & 0.40 & 0.51 & 0.64 & . \\
\hline Albania & 0.31 & 0.40 & 0.51 & 0.79 & 0.82 \\
\hline Algeria & 0.27 & 0.50 & 1.11 & 2.21 & . \\
\hline Angola & 0.21 & 0.24 & 0.29 & 0.36 & . \\
\hline Argentina & 2.97 & 3.85 & 5.24 & 6.67 & . \\
\hline Australia & 5.49 & 7.83 & 11.41 & 13.51 & 17.79 \\
\hline Austria & 1.92 & 3.20 & 5.76 & 10.10 & 12.05 \\
\hline Bangladesh & 0.13 & 0.16 & 0.23 & 0.34 & . \\
\hline Barbados & 2.49 & 2.79 & 4.51 & 9.13 & 20.45 \\
\hline Belgium & 7.44 & 11.56 & 19.72 & 34.43 & 40.79 \\
\hline Benin & 0.13 & 0.18 & 0.24 & 0.42 & . \\
\hline Bhutan & 0.04 & 0.05 & 0.06 & 0.08 & . \\
\hline Bolivia & 0.63 & 0.78 & 0.92 & 1.15 & 88.21 \\
\hline Botswana & 0.06 & 0.09 & 0.17 & 0.42 & . \\
\hline Brazil & 0.67 & 0.92 & 1.23 & 2.21 & 3.29 \\
\hline Bulgaria & 0.37 & 0.77 & 1.87 & 4.53 & . \\
\hline Burkina Faso & 0.09 & 0.11 & 0.13 & 0.15 & . \\
\hline Burma & 0.42 & 0.46 & 0.69 & 0.89 & 0.48 \\
\hline Burundi & 0.04 & 0.06 & 0.07 & 0.08 & . \\
\hline Cameroon & 0.09 & 0.12 & 0.20 & 0.43 & . \\
\hline Canada & 4.04 & 6.58 & 11.86 & 17.95 & 29.33 \\
\hline Cape Verde & 0.33 & 0.43 & 0.56 & 0.93 & 3.04 \\
\hline Central African Republic & 0.04 & 0.07 & 0.21 & 0.38 & 0.35 \\
\hline Chad & 0.03 & 0.06 & 0.11 & 0.20 & - \\
\hline Chile & 1.92 & 2.33 & 3.31 & 5.08 & 4.51 \\
\hline China & 0.13 & 0.20 & 0.28 & 0.35 & . \\
\hline Colombia & 0.75 & 0.99 & 1.55 & 1.92 & 76.88 \\
\hline Comoros & 0.10 & 0.12 & 0.15 & 0.21 & - \\
\hline Congo & 0.46 & 0.49 & 0.54 & 0.60 & . \\
\hline Costa Rica & 0.74 & 0.95 & 1.35 & 2.25 & 2.95 \\
\hline Cuba & 1.34 & 1.72 & 2.31 & 3.20 & . \\
\hline Cyprus & 1.08 & 1.39 & 1.60 & 2.84 & 6.33 \\
\hline Czechoslovakia & 1.56 & 2.90 & 4.92 & 6.53 & $\cdot$ \\
\hline Denmark & 2.89 & 4.58 & 7.95 & 12.69 & 17.69 \\
\hline Dominican Republic & 0.37 & 0.57 & 0.83 & 1.19 & . \\
\hline Ecuador & 0.53 & 0.70 & 0.98 & 1.59 & 2.24 \\
\hline Egypt & 0.66 & 0.72 & 0.92 & 1.19 & 1.53 \\
\hline El Salvador & 0.53 & 0.63 & 0.79 & 1.32 & 8.58 \\
\hline Equatorial Guinea & 0.13 & 0.22 & 0.33 & 0.52 & . \\
\hline Ethiopia & 0.10 & 0.14 & 0.18 & 0.25 & . \\
\hline Fiji & 0.50 & 0.68 & 0.94 & 1.17 & . \\
\hline Finland & 1.85 & 2.64 & 4.10 & 7.32 & 11.09 \\
\hline France & 2.24 & 3.53 & 6.35 & 10.66 & 17.65 \\
\hline Gabon & 0.12 & 0.17 & 0.26 & 0.33 & . \\
\hline Gambia & 0.11 & 0.13 & 0.15 & 0.19 & . \\
\hline Germany, East (former) & 3.33 & 4.69 & 6.96 & 8.44 & . \\
\hline
\end{tabular}


Annex 2 (cont'd): Ratio of non-agricultural labor force to agricultural labor force

\begin{tabular}{|c|c|c|c|c|c|}
\hline & 1950 & 1960 & 1970 & 1980 & 1990 \\
\hline Germany, West (former) & 3.34 & 6.07 & 12.36 & 16.33 & . \\
\hline Ghana & 0.38 & 0.57 & 0.71 & 0.79 & . \\
\hline Greece & 0.81 & 0.92 & 1.37 & 2.23 & . \\
\hline Guadeloupe & 0.80 & 1.37 & 2.48 & 5.69 & - \\
\hline Guatemala & 0.46 & 0.50 & 0.63 & 0.76 & 1.05 \\
\hline Guinea & 0.09 & 0.12 & 0.17 & 0.24 & - \\
\hline Guinea-Bissau & 0.12 & 0.15 & 0.19 & 0.21 & . \\
\hline Guyana & 1.27 & 1.63 & 2.13 & 2.74 & - \\
\hline Haiti & 0.17 & 0.25 & 0.34 & 0.43 & 0.74 \\
\hline Honduras & 0.38 & 0.42 & 0.54 & 0.65 & 1.84 \\
\hline Hungary & 0.93 & 1.63 & 2.98 & 4.50 & 4.11 \\
\hline Iceland & 1.66 & 3.04 & 4.80 & 8.77 & . \\
\hline India & 0.27 & 0.35 & 0.39 & 0.43 & . \\
\hline Indonesia & 0.27 & 0.34 & 0.51 & 0.75 & 0.83 \\
\hline Iran & 0.64 & 0.85 & 1.29 & 1.75 & . \\
\hline Iraq & 0.73 & 0.88 & 1.12 & 2.29 & . \\
\hline Ireland & 1.49 & 1.73 & 2.80 & 4.38 & 6.79 \\
\hline Israel & 4.41 & 5.95 & 9.35 & 15.10 & 24.53 \\
\hline Italy & 1.27 & 2.25 & 4.32 & 7.32 & 11.70 \\
\hline Ivory Coast & 0.11 & 0.18 & 0.31 & 0.53 & \\
\hline Jamaica & 1.12 & 1.41 & 2.01 & 2.20 & 3.33 \\
\hline Japan & 1.05 & 2.02 & 4.09 & 7.96 & 13.15 \\
\hline Jordan & 0.84 & 1.20 & 2.59 & 8.78 & . \\
\hline Kampuchea & 0.19 & 0.22 & 0.28 & 0.34 & - \\
\hline Kenya & 0.12 & 0.14 & 0.18 & 0.23 & . \\
\hline Korea, North & 0.41 & 0.62 & 0.89 & 1.34 & . \\
\hline Korea, South & 0.30 & 0.63 & 1.04 & 1.75 & 4.62 \\
\hline Laos & 0.18 & 0.20 & 0.27 & 0.32 & . \\
\hline Lebanon & 0.81 & 1.61 & 4.05 & 5.99 & . \\
\hline Lesotho & 0.04 & 0.07 & 0.11 & 0.16 & . \\
\hline Liberia & 0.22 & 0.25 & 0.29 & 0.35 & . \\
\hline Libya & 0.34 & 0.89 & 2.46 & 4.51 & . \\
\hline Luxembourg & 3.16 & 5.46 & 11.65 & 17.64 & 26.29 \\
\hline Madagascar & 0.12 & 0.16 & 0.19 & 0.24 & . \\
\hline Malawi & 0.04 & 0.07 & 0.10 & 0.20 & . \\
\hline Malaysia & 0.49 & 0.58 & 0.86 & 1.40 & 2.27 \\
\hline Mali & 0.06 & 0.09 & 0.12 & 0.17 & . \\
\hline Malta & 6.73 & 9.07 & 13.54 & 18.17 & 39.63 \\
\hline Martinique & 1.12 & 1.44 & 3.23 & 6.44 & . \\
\hline Mauritania & 0.05 & 0.08 & 0.18 & 0.44 & . \\
\hline Mauritius & 1.12 & 1.52 & 1.94 & 2.58 & 4.61 \\
\hline Mexico & 0.66 & 0.81 & 1.27 & 1.74 & 3.54 \\
\hline Mongolia & 0.46 & 0.64 & 1.09 & 1.51 & . \\
\hline Morocco & 0.41 & 0.52 & 0.74 & 1.19 & 29.48 \\
\hline Mozambique & 0.11 & 0.13 & 0.16 & 0.18 & - \\
\hline Namibia & 0.46 & 0.62 & 0.96 & 1.30 & - \\
\hline Nepal & 0.05 & 0.06 & 0.07 & 0.08 & . \\
\hline
\end{tabular}


Annex 2 (cont'd): Ratio of non-agricultural labor force to agricultural labor force

\begin{tabular}{|c|c|c|c|c|c|}
\hline & 1950 & 1960 & 1970 & 1980 & 1990 \\
\hline Netherlands & 4.66 & 8.33 & 13.70 & 17.10 & 22.78 \\
\hline Nicaragua & & 0.62 & 0.94 & 1.15 & . \\
\hline Niger & 0.03 & 0.04 & 0.06 & 0.10 & . \\
\hline Nigeria & 0.29 & 0.37 & 0.41 & 0.47 & . \\
\hline Norway & 2.80 & 4.04 & 7.49 & 10.98 & 15.35 \\
\hline Pakistan & 0.45 & 0.65 & 0.70 & 0.83 & 1.02 \\
\hline Panama & 0.77 & 0.96 & 1.40 & 2.15 & 3.36 \\
\hline Papua New Guinea & 4.32 & 5.77 & 7.44 & 7.89 & . \\
\hline Paraguay & 0.79 & 0.77 & 0.90 & 1.06 & 88.61 \\
\hline Peru & 0.73 & 0.91 & 1.12 & 1.50 & 112.90 \\
\hline Philippines & 0.49 & 0.63 & 0.83 & 0.93 & 1.41 \\
\hline Poland & 0.73 & 1.08 & 1.57 & 2.51 & 2.59 \\
\hline Portugal & 1.01 & 1.27 & 2.14 & 2.88 & 4.85 \\
\hline Reunion & 0.66 & 1.13 & 1.63 & 4.60 & . \\
\hline Romania & 0.39 & 0.55 & 1.05 & 2.27 & 2.50 \\
\hline Rwanda & 0.04 & 0.06 & 0.07 & 0.08 & 0.11 \\
\hline Senegal & 0.18 & 0.19 & 0.21 & 0.24 & . \\
\hline Sierra Leone & 0.17 & 0.23 & 0.32 & 0.44 & . \\
\hline Singapore & 11.18 & 12.51 & 28.12 & 62.05 & . \\
\hline Somalia & 0.16 & 0.21 & 0.26 & 0.32 & . \\
\hline South Africa & 1.90 & 2.12 & 2.04 & 5.07 & 9.16 \\
\hline Soviet Union (former) & 0.79 & 1.39 & 2.90 & 4.00 & . \\
\hline Spain & 1.00 & 1.38 & 2.85 & 4.84 & 7.91 \\
\hline Sri Lanka & 0.72 & 0.77 & 0.81 & 0.87 & 1.44 \\
\hline Sudan & 0.09 & 0.16 & 0.30 & 0.41 & . \\
\hline Suriname & 1.90 & 2.35 & 3.04 & 4.02 & 33.26 \\
\hline Swaziland & 0.79 & 0.13 & 0.24 & 0.35 & . \\
\hline Sweden & 3.81 & 6.09 & 11.03 & 16.61 & 29.72 \\
\hline Switzerland & 4.92 & 7.86 & 11.78 & 15.20 & 17.13 \\
\hline TMP & 0.30 & 0.32 & 0.34 & 0.36 & - \\
\hline Tanzania & 0.06 & 0.08 & 0.11 & 0.17 & . \\
\hline Thailand & 0.17 & 0.19 & 0.25 & 0.41 & 0.53 \\
\hline Togo & 0.22 & 0.26 & 0.30 & 0.37 & . \\
\hline Trimidad & 3.03 & 3.61 & 4.38 & 8.85 & . \\
\hline Tunisia & 0.47 & 0.78 & 1.37 & 1.86 & 3.63 \\
\hline Turkey & 0.15 & 0.27 & 0.41 & 0.71 & 1.29 \\
\hline Uganda & 0.06 & 0.08 & 0.12 & 0.16 & . \\
\hline United Kingdom & 17.24 & 23.88 & 34.54 & 37.42 & 48.98 \\
\hline United States & 7.13 & 14.07 & 22.33 & 27.91 & 34.45 \\
\hline Uruguay & 3.11 & 3.70 & 4.39 & 5.35 & 26.79 \\
\hline Venezusela & 1.33 & 2.00 & 2.85 & 5.24 & 7.47 \\
\hline Viet Nam & 0.20 & 0.23 & 0.31 & 0.48 & . \\
\hline Yemen, PDR & 0.42 & 0.72 & 0.97 & 1.43 & . \\
\hline Yugoslavia & 0.36 & 0.57 & 1.01 & 2.10 & - \\
\hline Zaire & 0.15 & 0.18 & 0.26 & 0.40 & - \\
\hline Zambia & 0.19 & 0.24 & 0.31 & 0.37 & . \\
\hline Zimbabwe & 0.20 & 0.23 & 0.29 & 0.37 & . \\
\hline
\end{tabular}


Annex 3: Average annual labor force growth rates (decade average)

\begin{tabular}{|c|c|c|c|c|}
\hline & 1950 & 1960 & 1970 & 1980 \\
\hline Afghanistan & 1.28 & 1.23 & 1.16 & 1.30 \\
\hline Albania & 1.16 & 1.25 & 1.34 & 1.31 \\
\hline Algeria & 1.06 & 1.03 & 1.38 & 1.44 \\
\hline Angola & 1.14 & 1.12 & 1.31 & 1.20 \\
\hline Argentina & 1.14 & 1.15 & 1.10 & 1.12 \\
\hline Australia & 1.22 & 1.28 & 1.26 & 1.18 \\
\hline Austria & 0.98 & 0.92 & 1.08 & 1.06 \\
\hline Bangladesh & 1.10 & 1.15 & 1.23 & 1.33 \\
\hline Barbados & 0.91 & 0.99 & 1.31 & 1.16 \\
\hline Belgium & 1.00 & 1.03 & 1.09 & 1.05 \\
\hline Benin & 1.03 & 1.15 & 1.22 & 1.24 \\
\hline Bhutan & 1.16 & 1.18 & 1.20 & 1.21 \\
\hline Bolivia & 1.17 & 1.19 & 1.23 & 1.31 \\
\hline Botswana & 1.16 & 1.13 & 1.35 & 1.39 \\
\hline Brazil & 1.31 & 1.35 & 1.40 & 1.24 \\
\hline Bulgaria & 1.03 & 1.04 & 1.02 & 1.00 \\
\hline Burkina Faso & 1.17 & 1.15 & 1.19 & 1.22 \\
\hline Burma & 1.15 & 1.22 & 1.25 & 1.21 \\
\hline Burundi & 1.18 & 1.13 & 1.14 & 1.24 \\
\hline Cameroon & 1.15 & 1.19 & 1.17 & 1.21 \\
\hline Canada & 1.23 & 1.30 & 1.36 & 1.13 \\
\hline Cape Verde & 1.16 & 1.37 & 1.11 & 1.38 \\
\hline Central African Republic & 1.08 & 1.09 & 1.13 & 1.15 \\
\hline Chad & 1.11 & 1.15 & 1.18 & 1.21 \\
\hline Chile & 1.16 & 1.18 & 1.27 & 1.26 \\
\hline China & 1.09 & 1.24 & 1.28 & 1.24 \\
\hline Colombia & 1.20 & 1.31 & 1.28 & 1.30 \\
\hline Comoros & 1.22 & 1.23 & 1.36 & 1.28 \\
\hline Congo & 1.18 & 1.20 & 1.23 & 1.20 \\
\hline Costa Rica & 1.29 & 1.40 & 1.46 & 1.32 \\
\hline Cuba & 1.15 & 1.10 & 1.35 & 1.25 \\
\hline Cyprus & 1.11 & 1.10 & 1.14 & 1.11 \\
\hline Czechoslovakia & 1.08 & 1.12 & 1.09 & 1.04 \\
\hline Denmark & 1.01 & 1.14 & 1.14 & 1.05 \\
\hline Dominican Republic & 1.19 & 1.24 & 1.36 & 1.39 \\
\hline Ecuador & 1.26 & 1.30 & 1.30 & 1.35 \\
\hline Egypt & 1.19 & 1.22 & 1.23 & 1.29 \\
\hline El Salvador & 1.23 & 1.41 & 1.34 & 1.36 \\
\hline Equatorial Guinea & 1.03 & 1.09 & 1.12 & 1.15 \\
\hline Ethiopia & 1.21 & 1.25 & 1.22 & 1.21 \\
\hline Fiji & 1.27 & 1.41 & 1.34 & 1.23 \\
\hline Finland & 1.01 & 1.09 & 1.08 & 1.07 \\
\hline France & 1.03 & 1.09 & 1.09 & 1.08 \\
\hline Gabon & 1.04 & 1.05 & 1.09 & 1.07 \\
\hline Gambia & 1.09 & 1.21 & 1.21 & 1.14 \\
\hline Germany, East (former) & 0.97 & 0.96 & 1.07 & 1.06 \\
\hline Germany, West (former) & 1.12 & 1.03 & 1.05 & 1.03 \\
\hline
\end{tabular}


Annex 3 (cont'd): Average annual labor force growth rates (decade average)

\begin{tabular}{|c|c|c|c|c|}
\hline & 1950 & 1960 & 1970 & 1980 \\
\hline Ghana & 1.47 & 1.16 & 1.27 & 1.31 \\
\hline Greece & 1.10 & 1.01 & 1.08 & 1.05 \\
\hline Guadeloupe & 1.20 & 1.08 & 1.24 & 1.18 \\
\hline Guatemala & 1.25 & 1.28 & 1.24 & 1.34 \\
\hline Guinea & 1.09 & 1.16 & 1.20 & 1.18 \\
\hline Guinea-Bissau & 1.05 & 0.94 & 1.46 & 1.14 \\
\hline Guyana & 1.16 & 1.24 & 1.45 & 1.32 \\
\hline Haiti & 1.12 & 1.14 & 1.09 & 1.22 \\
\hline Honduras & 1.32 & 1.28 & 1.37 & 1.46 \\
\hline Hungary & 1.13 & 1.14 & 0.95 & 1.01 \\
\hline Iceland & 1.11 & 1.27 & 1.33 & 1.16 \\
\hline India & 1.16 & 1.16 & 1.18 & 1.22 \\
\hline Indonesia & 1.17 & 1.22 & 1.23 & 1.27 \\
\hline Iran & 1.33 & 1.36 & 1.37 & 1.38 \\
\hline Iraq & 1.25 & 1.31 & 1.49 & 1.44 \\
\hline Ireland & 0.87 & 1.00 & 1.12 & 1.18 \\
\hline Israel & 1.54 & 1.44 & 1.32 & 1.25 \\
\hline Italy & 1.01 & 1.01 & 1.05 & 1.06 \\
\hline Ivory Coast & 1.10 & 1.34 & 1.29 & 1.30 \\
\hline Jamaica & 1.05 & 1.07 & 1.33 & 1.32 \\
\hline Japan & 1.22 & 1.19 & 1.07 & 1.09 \\
\hline Jordan & 1.37 & 1.33 & 1.10 & 1.54 \\
\hline Kampuchea & 1.22 & 1.24 & 1.08 & 1.14 \\
\hline Kenya & 1.34 & 1.38 & 1.43 & 1.42 \\
\hline Korea, North & 0.96 & 1.25 & 1.33 & 1.34 \\
\hline Korea, South & 1.12 & 1.36 & 1.29 & 1.27 \\
\hline Laos & 1.24 & 1.22 & 1.14 & 1.22 \\
\hline Lebanon & 1.14 & 1.27 & 1.13 & 1.23 \\
\hline Lesotho & 1.16 & 1.15 & 1.22 & 1.22 \\
\hline Liberia & 1.20 & 1.27 & 1.30 & 1.26 \\
\hline Libya & 1.18 & 1.38 & 1.45 & 1.42 \\
\hline Luxembourg & 0.97 & 0.99 & 1.17 & 1.02 \\
\hline Madagascar & 1.20 & 1.21 & 1.24 & 1.22 \\
\hline Malawi & 1.21 & 1.23 & 1.25 & 1.29 \\
\hline Malaysia & 1.18 & 1.30 & 1.44 & 1.32 \\
\hline Mali & 1.21 & 1.17 & 1.19 & 1.29 \\
\hline Malta & 0.95 & 1.13 & 1.23 & 1.10 \\
\hline Martinique & 1.12 & 1.10 & 1.24 & 1.15 \\
\hline Mauritania & 1.19 & 1.20 & 1.19 & 1.32 \\
\hline Mauritius & 1.27 & 1.32 & 1.28 & 1.33 \\
\hline Mexico & 1.25 & 1.31 & 1.54 & 1.37 \\
\hline Mongolia & 1.23 & 1.28 & 1.33 & 1.33 \\
\hline Morocco & 1.25 & 1.21 & 1.41 & 1.38 \\
\hline Mozambique & 1.14 & 1.20 & 1.46 & 1.22 \\
\hline Namibia & 1.17 & 1.19 & 1.19 & 1.26 \\
\hline Nepal & 1.12 & 1.11 & 1.19 & 1.26 \\
\hline Netherlands & 1.02 & 1.16 & 1.16 & 1.13 \\
\hline
\end{tabular}


Annex 3 (cont'd): Average annual labor force grownh rales (decado averngo)

\begin{tabular}{|c|c|c|c|c|}
\hline & 1950 & 1960 & 1970 & 1980 \\
\hline Nicnragua & . & 1.32 & 1.33 & 1.46 \\
\hline Nigor & 1.06 & 1.24 & 1.21 & 1.26 \\
\hline Nigeria & 1.26 & 1.30 & 1.36 & 1.30 \\
\hline Norway & 1.01 & 1.14 & 1.22 & 1.08 \\
\hline Pakistan & 1.08 & 1.22 & 1.31 & 1.33 \\
\hline Panams & 1.21 & 1.35 & 1.28 & 1.33 \\
\hline Pupun New Guinen & 1.21 & 1.24 & 1.21 & 1.18 \\
\hline Puraguay & 1.20 & 1.27 & 1.41 & 1.35 \\
\hline Peru & 1.23 & 1.22 & 1.39 & 1.33 \\
\hline Philippines & 1.20 & 1.29 & 1.28 & 1.28 \\
\hline Poland & 1.12 & 1.22 & 1.07 & 1.06 \\
\hline Portugal & 0.98 & 1.00 & 1.28 & 1.09 \\
\hline Reunion & 1.14 & 1.24 & 1.46 & 1.30 \\
\hline Romanis & 1.08 & 1.06 & 1.00 & 1.07 \\
\hline Rwanda & 1.26 & 1.28 & 1.36 & 1.32 \\
\hline Senegal & 1.19 & 1.30 & 1.38 & 1.21 \\
\hline Sierra Leone & 1.07 & 1.08 & 1.10 & 1.12 \\
\hline Singapore & 1.52 & 1.34 & 1.54 & 1.16 \\
\hline Somalia & 1.15 & 1.19 & 1.44 & 1.19 \\
\hline South Africa & 1.14 & 1.31 & 1.13 & 1.32 \\
\hline Soviet Union (former) & 1.17 & 1.07 & 1.17 & 1.07 \\
\hline Spain & 1.08 & 1.03 & 1.08 & 1.12 \\
\hline Sri Lanka & 1.20 & 1.22 & 1.26 & 1.17 \\
\hline Sudan & 1.17 & 1.19 & 1.30 & 1.33 \\
\hline Suriname & 1.13 & 1.23 & 1.05 & 1.30 \\
\hline Swaziland & 1.21 & 1.20 & 1.23 & 1.25 \\
\hline Sweden & 1.06 & 1.14 & 1.12 & 1.04 \\
\hline Switzerland & 1.17 & 1.19 & 1.03 & 1.05 \\
\hline TMP & 1.14 & 1.17 & 1.08 & 1.23 \\
\hline Tanzania & 1.28 & 1.30 & 1.33 & 1.32 \\
\hline Thailand & 1.24 & 1.33 & 1.32 & 1.25 \\
\hline Togo & 1.11 & 1.29 & 1.23 & 1.25 \\
\hline Trinidad & 1.21 & 1.13 & 1.25 & 1.26 \\
\hline Tunisia & 1.11 & 1.12 & 1.44 & 1.36 \\
\hline Turkey & 1.17 & 1.15 & 1.19 & 1.24 \\
\hline Uganda & 1.34 & 1.46 & 1.30 & 1.32 \\
\hline United Kingdom & 1.04 & 1.05 & 1.05 & 1.04 \\
\hline United States & 1.12 & 1.19 & 1.26 & 1.11 \\
\hline Uruguay & 1.11 & 1.08 & 1.02 & 1.07 \\
\hline Venezuela & 1.39 & 1.32 & 1.61 & 1.39 \\
\hline Viet Nam & 1.05 & 1.10 & 1.23 & 1.32 \\
\hline Yemen, PDR & 1.19 & 1.18 & 1.18 & 1.34 \\
\hline Yugoslavia & 1.10 & 1.10 & 1.09 & 1.09 \\
\hline Zaire & 1.23 & 1.14 & 1.20 & 1.25 \\
\hline Zambia & 1.26 & 1.29 & 1.31 & 1.38 \\
\hline Zimbabwe & 1.44 & 1.41 & 1.32 & 1.32 \\
\hline
\end{tabular}


Annex 4:

Migration (version 1)

\begin{tabular}{llll}
\hline $1950-60$ & $1960-70$ & $1970-80$ & $1980-90$
\end{tabular}

\% per annum

\begin{tabular}{|c|c|c|c|c|c|c|c|c|}
\hline \multirow[b]{2}{*}{ Afghanistan } & \multicolumn{4}{|c|}{$\%$ per annum } & \multicolumn{4}{|c|}{ \% per annum } \\
\hline & 0.68 & 0.93 & 0.89 & . & 2.46 & 2.98 & 3.27 & . \\
\hline Albania & 0.80 & 0.89 & 2.08 & 0.26 & 2.34 & 3.00 & 4.82 & 3.97 \\
\hline Algeria & 1.67 & 2.98 & 4.70 & - & 2.92 & 5.05 & 9.62 & . \\
\hline Angola & 0.29 & 0.39 & 0.67 & . & 1.38 & 1.60 & 2.32 & . \\
\hline Argentina & 2.07 & 2.57 & 2.05 & . & 8.89 & 10.15 & 10.04 & . \\
\hline Australia & 3.23 & 3.70 & 1.82 & 2.69 & 12.18 & 13.93 & 12.54 & 12.98 \\
\hline Austria & 2.96 & 3.49 & 4.23 & 1.59 & 7.74 & 9.15 & 12.25 & 10.44 \\
\hline Bangladesh & 0.26 & 0.62 & 1.00 & - & 0.96 & 1.48 & 2.25 & - \\
\hline Barbados & 0.72 & 3.08 & 5.96 & 6.12 & 5.76 & 8.84 & 15.00 & 15.64 \\
\hline Belgium & 3.29 & 4.05 & 4.54 & 1.60 & 11.19 & 12.81 & 14.47 & 11.54 \\
\hline Benin & 0.40 & 0.56 & 1.62 & - & 1.03 & 1.49 & 2.91 & . \\
\hline Bhutan & 0.08 & 0.12 & 0.21 & . & 0.33 & 0.42 & 0.58 & . \\
\hline Bolivia & 0.97 & 0.89 & 1.34 & 12.81 & 3.77 & 4.23 & 5.21 & 17.62 \\
\hline Botswana & 0.29 & 0.76 & 2.39 & . & 0.65 & 1.25 & 3.45 & . \\
\hline Brazil & 1.69 & 1.86 & 4.29 & 3.13 & 4.98 & 6.12 & 9.63 & 9.66 \\
\hline Bulgaria & 2.28 & 4.01 & 4.87 & . & 3.90 & 6.89 & 9.79 & - \\
\hline Burkina Faso & 0.19 & 0.25 & 0.22 & - & 0.69 & 0.84 & 0.96 & . \\
\hline Burma & 0.33 & 1.66 & 1.29 & -3.33 & 2.31 & 3.94 & 4.50 & 0.38 \\
\hline Burundi & 0.14 & 0.14 & 0.09 & . & 0.39 & 0.45 & 0.47 & . \\
\hline Cameroon & 0.34 & 0.78 & 1.90 & . & 0.82 & 1.45 & 2.95 & . \\
\hline Canada & 4.11 & 5.35 & 4.38 & 4.23 & 12.32 & 15.36 & 16.02 & 14.37 \\
\hline Cape Verde & 0.80 & 1.18 & 2.14 & 7.18 & 2.42 & 3.57 & 4.56 & 11.57 \\
\hline Central African Republic & 0.26 & 1.23 & 1.44 & -0.29 & 0.50 & 1.60 & 2.49 & 1.56 \\
\hline Chad & 0.31 & 0.49 & 0.90 & . & 0.48 & 0.84 & 1.52 & . \\
\hline Chile & 1.44 & 2.66 & 3.71 & -1.31 & 7.13 & 9.01 & 11.65 & $T .74$ \\
\hline China & 0.64 & 0.73 & 0.67 & - & 1.31 & 1.86 & 2.22 & - \\
\hline Colombia & 1.49 & 2.83 & 1.65 & 12.52 & 4.76 & 7.16 & 7.24 & 18.89 \\
\hline Comoros & 0.22 & 0.34 & 0.58 & . & 0.82 & 1.05 & 1.55 & - \\
\hline Congo & 0.30 & 0.36 & 0.49 & . & 2.49 & 2.73 & 3.10 & . \\
\hline Costa Rica & 1.42 & 2.37 & 4.06 & 2.32 & 4.90 & 6.88 & 9.96 & 9.29 \\
\hline Cuba & 1.62 & 1.94 & 2.89 & . & 6.25 & 7.05 & 10.14 & . \\
\hline Cyprus & 1.41 & 0.88 & 3.68 & 5.30 & 5.30 & 5.37 & 8.73 & 11.84 \\
\hline Czechoslovakia & 3.72 & 3.82 & 2.33 & . & 8.44 & 10.47 & 10.06 & . \\
\hline Denmark & 3.04 & 4.28 & 3.94 & 2.82 & 9.00 & 12.20 & 13.02 & 11.93 \\
\hline Dominican Republic & 1.48 & 1.74 & 2.25 & - & 3.35 & 4.49 & 6.22 & - \\
\hline Ecuador & 1.26 & 1.81 & 3.10 & 2.70 & 3.89 & 5.18 & 7.36 & 8.68 \\
\hline Egypt & 0.41 & 1.30 & 1.49 & 1.74 & 3.36 & 4.53 & 5.39 & 6.55 \\
\hline El Salvador & 0.74 & 1.25 & 3.07 & 10.30 & 3.31 & 4.61 & 6.86 & 15.70 \\
\hline Equatorial Guinea & 0.69 & 0.96 & 1.37 & . & 1.34 & 2.02 & 2.97 & . \\
\hline Ethiopia & 0.46 & 0.35 & 0.74 & . & 1.04 & 1.19 & 1.73 & . \\
\hline Fiji & 1.39 & 1.89 & 1.39 & . & 3.92 & 5.47 & 5.69 & . \\
\hline Finland & 2.18 & 3.10 & 4.19 & 3.35 & 7.03 & 9.29 & 11.46 & 11.76 \\
\hline France & 2.92 & 4.20 & 4.04 & 4.04 & 8.33 & 11.17 & 12.34 & 13.12 \\
\hline Gabon & 0.51 & 0.70 & 0.57 & . & 1.08 & 1.53 & 1.80 & . \\
\hline Gambia & 0.17 & 0.28 & 0.36 & . & 0.74 & 1.00 & 1.23 & . \\
\hline
\end{tabular}

Migration (version 2)

$1950-60 \quad 1960-70 \quad 1970-80 \quad 1980-90$

\% per annum 
Annex 4: Migration (version I) (cont'd) $\begin{array}{llll}1950-60 & 1960-70 & 1970-80 & 1980-90\end{array}$

\% per annum

\begin{tabular}{|c|c|c|c|c|c|c|c|c|}
\hline Germany, East (former) & 2.32 & 2.72 & 1.67 & - & 8.40 & 9.44 & 9.95 & - \\
\hline Germany, West (former) & 4.34 & 4.84 & 2.41 & - & 11.37 & 12.57 & 11.47 & - \\
\hline Ghana & 1.76 & 0.95 & 0.56 & - & 4.14 & 3.53 & 3.88 & - \\
\hline Greece & 0.63 & 1.92 & 2.88 & - & 3.78 & 5.09 & 7.24 & . \\
\hline Guadeloupe & 2.85 & 3.46 & 5.93 & - & 6.28 & 7.86 & 12.78 & - \\
\hline Guatemala & 0.33 & 1.01 & 0.90 & 1.87 & 2.67 & 3.57 & 3.87 & 5.55 \\
\hline Guinea & 0.35 & 0.50 & 0.63 & - & 0.81 & 1.18 & 1.59 & . \\
\hline Guinea-Bissau & 0.28 & 0.33 & 0.32 & - & 0.86 & 0.97 & 1.58 & - \\
\hline Guyana & 1.59 & 1.98 & 2.34 & . & 6.10 & 7.53 & 9.84 & . \\
\hline Haiti & 0.75 & 0.79 & 0.64 & 2.22 & 1.61 & 2.06 & 2.25 & 4.38 \\
\hline Honduras & 0.36 & 0.98 & 0.93 & 6.12 & 2.48 & 3.21 & 3.84 & 9.71 \\
\hline Hungary & 2.98 & 3.88 & 2.61 & -0.76 & 6.57 & 8.99 & 8.30 & 6.23 \\
\hline Iceland & 3.78 & 3.85 & 5.40 & - & 8.81 & 11.54 & 14.77 & - \\
\hline India & 0.65 & 0.37 & 0.33 & - & 2,05 & 2.10 & 2.28 & . \\
\hline Indonesia & 0.62 & 1.38 & 1.69 & 0.56 & 1.99 & 3.14 & 4.19 & 4.01 \\
\hline Iran & 1.55 & 2.56 & 2.31 & - & 4.77 & 6.62 & 7.65 & - \\
\hline Iraq & 1.04 & 1.49 & 5.25 & - & 4.35 & 5.49 & 10.60 & - \\
\hline Ireland & 0.78 & 2.82 & 3.30 & 3.64 & 4.50 & 7.48 & 9.83 & 11.72 \\
\hline Israel & 3.39 & 4.74 & 4.72 & 4.62 & 13.99 & 15.53 & 15.60 & 15.64 \\
\hline Italy & 3.04 & 3.94 & 3.77 & 3.67 & 6.99 & 9.29 & 10.93 & 12.03 \\
\hline Ivory Coast & 0.68 & 1.30 & 1.89 & - & 1.24 & 2.41 & 3.61 & - \\
\hline Jamaica & 1.28 & 2.13 & 0.77 & 3.43 & 5.04 & 6.55 & 7.45 & 10.33 \\
\hline Japan & 3.94 & 4.83 & 4.63 & 3.99 & 8.14 & 10.83 & 11.83 & 12.70 \\
\hline Jordan & 2.26 & 5.16 & 6.99 & - & 6.29 & 10.15 & 13.23 & - \\
\hline Kampuchea & 0.29 & 0.54 & 0.54 & . & 1.36 & 1.78 & 1.85 & - \\
\hline Kenya & 0.30 & 0.40 & 0.64 & - & 1.05 & 1.33 & 1.82 & - \\
\hline Korea, North & 1.26 & 1.80 & 2.51 & - & 2.90 & 4.78 & 6.61 & - \\
\hline Korea, South & 2.28 & 2.71 & 3.35 & 6.47 & 3.74 & 5.98 & 7.75 & 12.38 \\
\hline Laos & 0.27 & 0.61 & 0.46 & . & 1.28 & 1.74 & 1.81 & . \\
\hline Lebanon & 3.48 & 6.11 & 3.13 & - & 6.76 & 11.76 & 10.67 & - \\
\hline Lesotho & 0.34 & 0.43 & 0.50 & - & 0.56 & 0.83 & 1.15 & . \\
\hline Liberia & 0.36 & 0.35 & 0.55 & - & 1.53 & 1.78 & 2.19 & - \\
\hline Libya & 3.43 & 6.26 & 5.41 & - & 5.12 & 10.49 & 13.43 & - \\
\hline Luxembourg & 3.45 & 4.82 & 3.75 & 3.23 & 9.39 & 12.03 & 13.70 & 12.39 \\
\hline Madagascar & 0.33 & 0.39 & 0.42 & - & 1.03 & 1.27 & 1.52 & - \\
\hline Malawi & 0.32 & 0.38 & 0.99 & - & 0.57 & 0.80 & 1.61 & - \\
\hline Malaysia & 0.71 & 1.95 & 3.28 & 3.50 & 3.01 & 4.88 & 7.62 & 8.97 \\
\hline Mali & 0.32 & 0.32 & 0.49 & - & 0.69 & 0.83 & 1.17 & . \\
\hline Malta & 2.20 & 3.47 & 2.96 & 5.83 & 9.49 & 12.73 & 13.64 & 15.77 \\
\hline Martintque & 1.49 & 4.67 & 5.35 & - & 5.50 & 9.30 & 13.01 & - \\
\hline Mauritania & 0.28 & 1.07 & 2.17 & - & 0.57 & 1.50 & 3.15 & . \\
\hline
\end{tabular}


Annex 4:

Migration (version 1) (cont'd)

$\begin{array}{llll}1950-60 & 1960-70 & 1970-80 & 1980-90\end{array}$
Migration (version 2) (cont'd)

$\begin{array}{llll}1950-60 & 1960-70 & 1970-80 & 1980-90\end{array}$

\% per annum

$\%$ per annum

\begin{tabular}{|c|c|c|c|c|c|c|c|c|}
\hline Mauritius & 2.03 & 1.85 & 2.31 & 4.79 & 6.58 & 7.54 & 8.63 & 12.27 \\
\hline Mexico & 1.09 & 2.62 & 2.64 & 5.44 & 4.19 & 6.41 & 8.59 & 11.81 \\
\hline Mongolia & 1.39 & 2.74 & 2.23 & - & 3.69 & 5.85 & 6.91 & . \\
\hline Morocco & 0.96 & 1.49 & 2.93 & 12.77 & 3.07 & 4.00 & 6.71 & 17.90 \\
\hline Mozambique & 0.23 & 0.26 & 0.33 & - & 0.82 & 1.00 & 1.39 & . \\
\hline Namibia & 1.14 & 2.09 & 1.76 & . & 3.31 & 4.89 & 5.64 & . \\
\hline Nepal & 0.16 & 0.08 & 0.08 & . & 0.40 & 0.41 & 0.48 & . \\
\hline Netherlands & 4.00 & 4.23 & 2.17 & 2.69 & 11.10 & 13.57 & 12.27 & 12.78 \\
\hline Nicaragua & & 2.20 & 1.28 & - & . & 5.32 & 5.55 & . \\
\hline Niger & 0.08 & 0.25 & 0.41 & . & 0.24 & 0.49 & 0.76 & - \\
\hline Nigeria & 0.67 & 0.39 & 0.54 & - & 2.28 & 2.40 & 2.84 & . \\
\hline Norway & 2.48 & 4.64 & 3.56 & 2.90 & 8.36 & 12.28 & 13.20 & 12.08 \\
\hline Pakistan & 1.26 & 0.39 & 0.95 & 1.23 & 3.26 & 3.38 & 4.36 & 5.12 \\
\hline Panama & 1.16 & 2.50 & 3.02 & 3.69 & 4.54 & 6.87 & 8.29 & 10.58 \\
\hline Papua New Guinea & 2.60 & 2.45 & 0.62 & - & 10.90 & 11.65 & 10.19 & . \\
\hline Paraguay & -0.12 & 0.87 & 1.09 & 13.14 & 3.27 & 4.39 & 5.48 & 17.80 \\
\hline Peru & 1.14 & 1.21 & 2.09 & 12.99 & 4.44 & 5.02 & 7.09 & 18.68 \\
\hline Philippines & 1.05 & 1.35 & 0.70 & 2.53 & 3.42 & 4.46 & 4.43 & 6.61 \\
\hline Poland & 1.88 & 2.32 & 2.86 & 0.26 & 4.88 & 6.58 & 7.55 & 6.18 \\
\hline Portugal & 1.11 & 2.78 & 2.45 & 3.67 & 4.41 & 6.64 & 9.09 & 10.11 \\
\hline Reunion & 2.52 & 2.33 & 7.74 & - & 5.34 & 6.80 & 14.29 & . \\
\hline Romania & 1.14 & 2.59 & 3.73 & 0.69 & 2.89 & 4.88 & 7.18 & 6.39 \\
\hline Rwanda & 0.13 & 0.15 & 0.13 & 0.38 & 0.40 & 0.49 & 0.57 & 0.87 \\
\hline Senegal & 0.16 & 0.18 & 0.35 & - & 1.13 & 1.32 & 1.66 & - \\
\hline Sierra Leone & 0.53 & 0.78 & 0.86 & - & 1.36 & 1.89 & 2.40 & - \\
\hline Singapore & 1.49 & 7.20 & 8.27 & . & 14.35 & 18.79 & 22.62 & . \\
\hline Somalia & 0.49 & 0.50 & 0.69 & - & 1.32 & 1.61 & 2.36 & - \\
\hline South Africa & 0.81 & -0.35 & 5.66 & 5.30 & 6.35 & 6.40 & 11.39 & 14.74 \\
\hline Soviet Union (former) & 2.91 & 4.13 & 2.58 & - & 6.24 & 8.50 & 9.49 & . \\
\hline Spain & 1.73 & 3.95 & 3.68 & 3.86 & 5.33 & 8.17 & 10.01 & 11.80 \\
\hline Sri Lanka & 0.31 & 0.28 & 0.43 & 2.72 & 3.49 & 3.68 & 4.05 & 6.27 \\
\hline Sudan & 0.78 & 1.24 & 0.99 & . & 1.27 & 2.14 & 2.68 & . \\
\hline Suriname & 1.51 & 2.11 & 2.05 & 11.06 & 7.03 & 8.73 & 8.37 & 19.72 \\
\hline Swaziland & 0.37 & 1.09 & 1.00 & - & 0.90 & 1.81 & 2.32 & . \\
\hline Sweden & 3.41 & 4.68 & 3.54 & 4.43 & 10.39 & 13.26 & 12.99 & 13.69 \\
\hline Switzerland & 3.89 & 3.65 & 2.17 & 1.12 & 12.23 & 13.14 & 10.95 & 10.39 \\
\hline TMP & 0.19 & 0.18 & 0.17 & . & 1.67 & 1.79 & 1.74 & . \\
\hline Tanzania & 0.21 & 0.31 & 0.70 & - & 0.60 & 0.81 & 1.37 & . \\
\hline Thailand & 0.28 & 0.63 & 1.47 & 0.98 & 1.24 & 1.81 & 2.95 & 3.11 \\
\hline Togo & 0.31 & 0.46 & 0.60 & - & 1.42 & 1.93 & 2.21 & . \\
\hline Trinidad & 1.52 & 1.62 & 5.68 & . & 8.83 & 8.89 & 14.26 & . \\
\hline Tunisia & 1.94 & 2.79 & 2.45 & 5.21 & 4.06 & 5.95 & 8.30 & 11.76 \\
\hline Turkey & 1.11 & 1.17 & 2.07 & 3.14 & 1.92 & 2.54 & 4.11 & 6.40 \\
\hline Uganda & 0.24 & 0.51 & 0.50 & . & 0.64 & 1.08 & 1.23 & . \\
\hline
\end{tabular}


Annex 4:

Migration (version 1) (cont'd)

$$
\begin{array}{llll}
1950-60 \quad 1960-70 \quad 1970-80 & 1980-90
\end{array}
$$

\% per annum

\begin{tabular}{|c|c|c|c|c|c|c|c|c|}
\hline United Kingdom & 2.78 & 3.15 & 0.79 & 2.40 & 12.09 & 12.83 & 10.70 & 12.25 \\
\hline United States & 5.17 & 4.22 & 2.43 & 2.05 & 13.93 & 14.66 & 13.99 & 12.41 \\
\hline Uruguay & 1.39 & 1.38 & 1.55 & 8.27 & 8.13 & 8.38 & 8.57 & 16.08 \\
\hline Venezuela & 3.08 & 2.93 & 6.15 & 3.66 & 8.64 & 9.55 & 15.61 & 13.69 \\
\hline Viet $\mathbf{N a m}$ & 0.23 & 0.66 & 1.47 & . & 1.19 & 1.77 & 3.09 & . \\
\hline Yemen, PDR & 2.05 & 1.49 & 2.26 & . & 4.13 & 4.63 & 6.13 & . \\
\hline Yugoslavia & 1.43 & 2.40 & 3.82 & . & 3.12 & 4.83 & 7.46 & . \\
\hline Zaire & 0.29 & 0.78 & 1.15 & . & 1.15 & 1.71 & 2.56 & - \\
\hline Zambia & 0.52 & 0.67 & 0.60 & . & 1.59 & 2.04 & 2.33 & - \\
\hline Zimbabwe & 0.42 & 0.65 & 0.77 & . & 1.72 & 2.13 & 2.47 & - \\
\hline
\end{tabular}


Arnex 5:

Migration (version 3)

Migration (version 4)

\begin{tabular}{llll}
\hline $1950-60$ & $1960-70$ & $1970-80$ & $1980-90$
\end{tabular}

$\%$ per annum

\% per annum

\begin{tabular}{|c|c|c|c|c|c|c|c|c|}
\hline Afghanistan & 1.51 & 1.88 & 1.97 & . & 2.74 & 3.15 & 3.25 & - \\
\hline Albania & 1.52 & 1.87 & 3.32 & 1.89 & 2.60 & 3.17 & 4.79 & 3.24 \\
\hline Algeria & 2.26 & 3.92 & 6.79 & . & 3.18 & 5.04 & 7.87 & . \\
\hline Angola & 0.81 & 0.96 & 1.45 & . & 1.67 & 1.88 & 2.63 & . \\
\hline Argentina & 4.69 & 5.42 & 4.98 & - & 3.94 & 4.18 & 3.29 & . \\
\hline Australia & 6.50 & 7.36 & 5.58 & 6.27 & 4.55 & 4.75 & 2.56 & 3.29 \\
\hline Austria & 4.88 & 5.65 & 7.15 & 4.71 & 4.94 & 4.94 & 5.35 & 2.28 \\
\hline Bangladesh & 0.60 & 1.03 & 1.59 & - & 1.20 & 1.76 & 2.56 & . \\
\hline Barbados & 2.70 & 5.31 & 9.32 & 9.49 & 2.37 & 4.76 & 7.60 & 6.95 \\
\hline Belgium & 6.12 & 7.12 & 7.96 & 4.97 & 4.14 & 4.65 & 4.93 & 1.82 \\
\hline Benin & 0.71 & 1.01 & 2.23 & - & 1.26 & 1.78 & 3.22 & . \\
\hline Bhutan & 0.20 & 0.27 & 0.39 & . & 0.44 & 0.55 & 0.73 & . \\
\hline Bolivia & 2.22 & 2.35 & 3.01 & 14.84 & 3.50 & 3.59 & 4.17 & 15.82 \\
\hline Botswana & 0.47 & 1.00 & 2.90 & - & 0.80 & 1.44 & 3.78 & - \\
\hline Brazil & 3.15 & 3.70 & 6.53 & 5.72 & 4.56 & 4.97 & 7.49 & 5.51 \\
\hline Bulgaria & 3.03 & 5.28 & 6.85 & - & 4.07 & 6.36 & 6.96 & - \\
\hline Burkina Faso & 0.44 & 0.54 & 0.58 & - & 0.89 & 1.06 & 1.22 & . \\
\hline Burma & 1.24 & 2.70 & 2.71 & -1.72 & 2.45 & 4.01 & 4.05 & -0.55 \\
\hline Burundi & 0.26 & 0.29 & 0.28 & . & 0.51 & 0.59 & 0.64 & - \\
\hline Cameroon & 0.58 & 1.10 & 2.40 & - & 1.01 & 1.70 & 3.25 & - \\
\hline Canada & 7.19 & 8.97 & 8.45 & $\mathbf{7 . 7 3}$ & 5.78 & 6.58 & 5.15 & 4.67 \\
\hline Cape Verde & 1.56 & 2.28 & 3.23 & 9.07 & 2.67 & 3.72 & 4.45 & 10.35 \\
\hline Central African Republic & 0.38 & 1.41 & 1.94 & 0.57 & 0.60 & 1.76 & 2.78 & 1.75 \\
\hline Chad & 0.40 & 0.66 & 1.20 & . & 0.56 & 0.98 & 1.75 & . \\
\hline Chile & 3.72 & 5.16 & 6.74 & 2.02 & 3,80 & 4.87 & 5.68 & 0.14 \\
\hline China & 0,96 & 1.27 & 1.40 & . & 1.55 & 2.18 & 2.53 & . \\
\hline Colombia & 2.93 & 4.69 & 3.95 & 15.08 & 4.19 & 5.84 & 4.45 & 15.16 \\
\hline Comoros & 0.51 & 0.68 & 1.05 & - & 1.05 & 1.31 & 1.87 & . \\
\hline Congo & 1.30 & 1.44 & 1.67 & - & 2.57 & 2.75 & 3.02 & . \\
\hline Costa Rica & 2.95 & 4.31 & 6.52 & 5.07 & 4.31 & 5.59 & 7.35 & 4.82 \\
\hline Cuba & 3.55 & 4.02 & 5.75 & - & 4.21 & 4.27 & 5.43 & . \\
\hline Cyprus & 3.06 & 2.74 & 5.74 & 7.83 & 3.96 & 3.33 & 6.13 & 7.19 \\
\hline Czechoslovakia & 5.65 & 6.39 & 5.18 & - & 6.06 & 5.70 & 3.61 & . \\
\hline Denmark & 5.34 & 7.22 & 7.18 & 6.00 & 4.73 & 5.69 & 4.85 & 3.38 \\
\hline Dominican Republic & 2.34 & 2.98 & 3.98 & . & 3.55 & 4.34 & 5.35 & . \\
\hline Ecuador & 2.45 & 3.30 & 4.93 & 5.15 & 3.83 & 4.69 & 6.10 & 5.61 \\
\hline Egypt & 1.72 & 2.73 & 3.17 & 3.76 & 3.01 & 4.02 & 4.33 & 4.69 \\
\hline El Salvador & 1.90 & 2.75 & 4.73 & 12.55 & 3.25 & 4.29 & 6.11 & 13.37 \\
\hline Equatorial Guinea & 1.01 & 1.46 & 2.12 & . & 1.57 & 2.30 & 3.20 & . \\
\hline Ethiopia & 0.74 & 0.76 & 1.22 & . & 1.27 & 1.47 & 2.04 & . \\
\hline Fiji & 2.54 & 3.48 & 3.24 & . & 3.93 & 5.00 & 4.49 & . \\
\hline Finland & 4.14 & 5.51 & 6.91 & 6.37 & 4.26 & 5.01 & 5.64 & 4.27 \\
\hline France & 5.06 & 6.84 & 7.05 & 7.23 & 4.88 & 5.82 & 5.10 & 4.71 \\
\hline Gabon & 0.78 & 1.10 & 1.16 & . & 1.29 & 1.79 & 2.08 & . \\
\hline Gambia & 0.45 & 0.63 & 0.78 & . & 0.96 & 1.26 & 1.52 & . \\
\hline
\end{tabular}


Annex 5:

Migration (version 3) (cont'd)

$\begin{array}{llll}1950-60 & 1960-70 & 1970-80 & 1980-90\end{array}$
Migration (version 4) (cont'd)

$1950-60 \quad 1960-70 \quad 1970-80 \quad 1980-90$

$\%$ per annum

\% per annum

\begin{tabular}{|c|c|c|c|c|c|c|c|c|}
\hline Germany, East (former) & 4.63 & 5.21 & 4.65 & . & 3.81 & 3.89 & 2.63 & . \\
\hline Germany, West (former) & 7.02 & 7.65 & 5.58 & . & 6.06 & 5.87 & 2.99 & . \\
\hline Ghana & 2.86 & 2.11 & 2.03 & - & 4.37 & 3.38 & 3.38 & . \\
\hline Greece & 2.01 & 3.29 & 4.69 & . & 3.12 & 4.24 & 5.29 & . \\
\hline Guadeloupe & 4.35 & 5.29 & 8.61 & . & 5.58 & 5.89 & 8.18 & . \\
\hline Guatemala & 1.40 & 2.18 & 2.23 & 3.49 & 2.74 & 3.57 & 3.58 & 4.89 \\
\hline Guinea & 0.57 & 0.83 & 1.09 & - & 0.99 & 1.42 & 1.88 & . \\
\hline Guinea-Bissau & 0.56 & 0.64 & 0.92 & . & 1.07 & 1.19 & 1.95 & . \\
\hline Guyana & 3.48 & 4.25 & 5.32 & - & 4.22 & 4.63 & 5.17 & . \\
\hline Haiti & 1.16 & 1.39 & 1.39 & 3.21 & 1.88 & 2.35 & 2.46 & 4.51 \\
\hline Honduras & 1.34 & 2.01 & 2.24 & 7.72 & 2.69 & 3.35 & 3.74 & 9.31 \\
\hline Hungary & 4.53 & 5.97 & 4.80 & 1.84 & 5.58 & 6.33 & 4.17 & 0.51 \\
\hline Iceland & 5.83 & 6.81 & 8.86 & - & 6.14 & 5.92 & 6.99 & . \\
\hline India & 1.31 & 1.18 & 1.23 & . & 2.34 & 2.33 & 2.46 & . \\
\hline Indonesia & 1.27 & 2.20 & 2.82 & 2.08 & 2.28 & 3.39 & 4.17 & 3.41 \\
\hline Iran & 2.99 & 4.33 & 4.54 & . & 4.44 & 5.67 & 5.40 & . \\
\hline Iraq & 2.50 & 3.22 & 7.52 & . & 3.83 & 4.49 & 8.67 & - \\
\hline Ireland & 2.31 & 4.71 & 5.83 & 6.65 & 2.70 & 4.93 & 5.21 & 5.14 \\
\hline Israel & 7.33 & 8.67 & 8.57 & 8.44 & 5.35 & 6.21 & 5.65 & 5.19 \\
\hline Italy & 4.69 & 6.06 & 6.44 & 6.67 & 5.34 & 5.86 & 5.13 & 4.59 \\
\hline Ivory Coast & 0.95 & 1.83 & 2.70 & . & 1.46 & 2.74 & 3.91 & . \\
\hline Jamaica & 2.87 & 3.96 & 3.44 & 6.17 & 3.69 & 4.51 & 3.42 & 5.96 \\
\hline Japan & 5.73 & 7.23 & 7.33 & 7.11 & 6.75 & 7.20 & 6.07 & 4.87 \\
\hline Jordan & 4.02 & 7.26 & 9.42 & . & 5.38 & 8.19 & 8.95 & - \\
\hline Kampuchea & 0.81 & 1.13 & 1.15 & . & 1.67 & 2.09 & 2.11 & . \\
\hline Kenya & 0.66 & 0.85 & 1.21 & . & 1.33 & 1.65 & 2.17 & . \\
\hline Korea, North & 2.01 & 3.13 & 4.29 & - & 3.02 & 4.50 & 5.56 & - \\
\hline Korea, South & 2.97 & 4.17 & 5.23 & 8.87 & 4.00 & 5.66 & 6.33 & 9.13 \\
\hline Laos & 0.76 & 1.15 & 1.10 & . & 1.59 & 2.05 & 2.09 & . \\
\hline Lebanon & 4.91 & 8.42 & 5.95 & . & 6.07 & 8.84 & 4.65 & . \\
\hline Lesotho & 0.45 & 0.63 & 0.81 & . & 0.67 & 0.99 & 1.39 & . \\
\hline
\end{tabular}


Annex 5:

Migration (version 3) (cont'd)

\begin{tabular}{llll}
\hline $1950-60$ & $1960-70$ & $1970-80$ & $1980-90$
\end{tabular}

Migration (version 4) (com'd)

$\begin{array}{llll}1950-60 & 1960-70 & 1970-80 & 1980-90\end{array}$

\begin{tabular}{|c|c|c|c|c|c|c|c|c|}
\hline & & \% per & & & & \% pe & & \\
\hline Liberia & 0.92 & 1.03 & 1.32 & . & 1.84 & 2.10 & 2.50 & . \\
\hline Libya & 4.22 & 8.10 & 8.55 & . & 5.36 & 9.43 & 8.06 & . \\
\hline Luxembourg & 5.73 & 7.46 & 7.24 & 6.39 & 4.99 & 5.89 & 4.42 & 3.64 \\
\hline Madagascar & 0.67 & 0.81 & 0.95 & . & 1.28 & 1.55 & 1.83 & . \\
\hline Malawi & 0.44 & 0.59 & 1.30 & . & 0.68 & 0.98 & 1.85 & . \\
\hline Malaysia & 1.75 & 3.27 & 5.16 & 5.77 & 3.03 & 4.70 & 6.59 & 6.45 \\
\hline Mali & 0.50 & 0.57 & 0.82 & . & 0.84 & 1.03 & 1.42 & * \\
\hline Malta & 4.83 & 6.75 & 6.68 & 9.25 & 3.07 & 4.28 & 3.58 & 6.25 \\
\hline Martinique & 3.19 & 6.59 & 8.28 & . & 4.06 & 7.12 & 7.29 & . \\
\hline Mauritania & 0.42 & 1.28 & 2.64 & . & 0.70 & 1.68 & 3.45 & . \\
\hline Mauritius & 3.96 & 4.19 & 4.85 & 7.71 & 4.94 & 4.73 & 4.91 & 7.15 \\
\hline Mexico & 2.47 & 4.27 & 5.13 & 8.03 & 3.84 & 5.60 & 6.12 & 8.33 \\
\hline Mongolia & 2.44 & 4.13 & 4.22 & . & 3.77 & 5.53 & 5.28 & . \\
\hline Morocco & 1.93 & 2.63 & 4.59 & 14.93 & 3.24 & 3.96 & 6.08 & 15.91 \\
\hline Mozambique & 0.52 & 0.62 & 0.84 & . & 1.05 & 1.26 & 1.73 & . \\
\hline Namibia & 2.14 & 3.34 & 3.43 & . & 3.39 & 4.64 & 4.52 & . \\
\hline Nepal & 0.28 & 0.24 & 0.28 & . & 0.52 & 0.55 & 0.64 & . \\
\hline Netherlands & 6.63 & 7.56 & 5.69 & 6.18 & 5.24 & 5.13 & 2.75 & 3.15 \\
\hline Nicaragua & . & 3.59 & 3.12 & . & & 5.04 & 4.36 & . \\
\hline Niger & 0.16 & 0.37 & 0.58 & . & 0.32 & 0.60 & 0.92 & . \\
\hline Nigeria & 1.43 & 1.32 & 1.60 & . & 2.58 & 2.63 & 3.02 & . \\
\hline Norway & 4.76 & 7.50 & 7.02 & 6.12 & 4.20 & 6.18 & 4.60 & 3.56 \\
\hline Pakistan & 2.18 & 1.72 & 2.46 & 2.92 & 3.34 & 3.05 & 3.87 & 4.25 \\
\hline Panama & 2.64 & 4.38 & 5.21 & 6.43 & 3.90 & 5.61 & 5.87 & 6.27 \\
\hline Papua New Guinea & 5.69 & 5.80 & 4.05 & . & 4.17 & 3.74 & 1.65 & . \\
\hline Paraguay & 1.36 & 2.42 & 2.99 & 15.13 & 2.60 & 3.73 & 4.34 & 16.25 \\
\hline Peru & 2.60 & 2.86 & 4.21 & 15.33 & 3.90 & 4.01 & 5.28 & 15.91 \\
\hline Philippines & 2.13 & 2.74 & 2.32 & 4.29 & 3.43 & 4.15 & 3.61 & 5.49 \\
\hline Poland & 3.20 & 4.13 & 4.78 & 2.58 & 4.39 & 5.12 & 5.17 & 2.18 \\
\hline Portugal & 2.52 & 4.40 & 5.09 & 6.15 & 3.38 & 5.04 & 4.94 & 5.49 \\
\hline Reunion & 3.77 & 4.22 & 10.42 & . & 5.01 & 5.17 & 10.88 & . \\
\hline Romania & 1.95 & 3.62 & 5.20 & 2.94 & 3.05 & 4.78 & 6.04 & 2.72 \\
\hline Rwanda & 0.27 & 0.32 & 0.35 & 0.62 & 0.53 & 0.64 & 0.76 & 1.08 \\
\hline Senegal & 0.63 & 0.73 & 0.98 & . & 1.42 & 1.65 & 2.01 & . \\
\hline Sierra Leone & 0.93 & 1.31 & 1.58 & . & 1.62 & 2.17 & 2.64 & . \\
\hline Singapore & 6.00 & 11.25 & 13.16 & . & 2.40 & 7.93 & 8.66 & . \\
\hline Somalia & 0.89 & 1.03 & 1.48 & . & 1.59 & 1.91 & 2.72 & . \\
\hline South Africa & 3.03 & 2.33 & 7.95 & 8.77 & 3.13 & 2.21 & 7.92 & 6.82 \\
\hline Soviet Union (former) & 4.37 & 5.94 & 5.25 & & 5.57 & 6.51 & 4.53 & . \\
\hline Spain & 3.27 & 5.70 & 6.13 & 6.79 & 4.23 & 6.26 & 5.50 & 5.20 \\
\hline Sri Lanka & 1.71 & 1.77 & 2.02 & 4.26 & 2.99 & 3.05 & 3.29 & 5.40 \\
\hline Sudan & 1.02 & 1.67 & 1.78 & . & 1.46 & 2.43 & 2.98 & 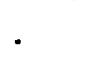 \\
\hline Suriname & 3.73 & 4.72 & 4.48 & 14.31 & 3.82 & 4.40 & 3.75 & 12.82 \\
\hline Swaziland & 0.63 & 1.44 & 1.63 & . & 1.11 & 2.06 & 2.64 & . \\
\hline Sweden & 6.04 & 7.80 & 6.86 & 7.63 & 4.91 & 5.82 & 4.21 & 4.86 \\
\hline
\end{tabular}


Annex 5:

Migration (version 3) (cont'd)

Migration (version 4) (cont'd) -

\begin{tabular}{|c|c|c|c|c|c|c|c|}
\hline & \\
\hline $1950-60$ & $1960-70$ & $1970-80$ & $1980-90$ & $1950-60$ & $1960-70$ & $1970-80$ & $1980-90$ \\
\hline \multicolumn{4}{|c|}{$\%$ per annum } & \multicolumn{4}{|c|}{ \% per annum } \\
\hline 6.97 & 7.04 & 5.25 & 4.33 & 5.27 & 4.61 & 2.76 & 1.59 \\
\hline 0.89 & 0.93 & 0.90 & . & 1.94 & 2.04 & 1.96 & 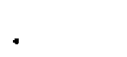 \\
\hline 0.40 & 0.55 & 1.03 & . & 0.77 & 1.01 & 1.62 & . \\
\hline 0.74 & 1.19 & 2.17 & 1.96 & 1.54 & 2.14 & 3.29 & 3.27 \\
\hline 0.84 & 1.16 & 1.36 & . & 1.70 & 2.25 & 2.49 & . \\
\hline 4.33 & 4.37 & 8.87 & . & 3.50 & 3.27 & 7.28 & . \\
\hline 2.91 & 4.18 & 4.88 & 7.85 & 4.11 & 5.34 & 5.67 & 8.01 \\
\hline 1.50 & 1.82 & 3.01 & 4.58 & 2.19 & 2.83 & 4.25 & 5.91 \\
\hline 0.44 & 0.79 & 0.85 & . & 0.82 & 1.31 & 1.50 & . \\
\hline 5.99 & 6.46 & 4.15 & 5.74 & 3.20 & 3.46 & 1.01 & 2.60 \\
\hline 8.32 & 7.85 & 6.39 & 5.58 & 6.16 & 4.80 & 2.83 & 2.33 \\
\hline 3.97 & 4.02 & 4.16 & 11.14 & 3.17 & 2.93 & 2.86 & 9.46 \\
\hline 5.40 & 5.58 & 9.80 & 7.34 & 6.21 & 5.58 & 8.86 & 5.21 \\
\hline 0.69 & 1.19 & 2.23 & . & 1.45 & 2.05 & 3.37 & . \\
\hline 3.00 & 2.88 & 3.93 & . & 4.26 & 4.13 & 5.00 & . \\
\hline 2.21 & 3.49 & 5.38 & . & 3.32 & 4.70 & 6.33 & . \\
\hline 0.71 & 1.23 & 1.82 & . & 1.44 & 1.99 & 2.86 & . \\
\hline 1.03 & 1.32 & 1.41 & . & 1.90 & 2.37 & 2.63 & . \\
\hline 1.04 & 1.36 & 1.57 & . & 2.09 & 2.49 & 2.78 & . \\
\hline
\end{tabular}


This

WPS1411 Income Inequality, Welfare, and
Poverty: An Illustration Using
Ukrainian Data

WPS1418 The Impact of Labor Market Regulations

WPS1419 Industry Structure and Pegulation

WPS1420 Legislative Frameworks Used to Foster Petroleum Development

WPS1421 Distribution of Income and the Income Zeljko Bogetic Tax Burden in Bulgaria

WPS1422 Efficiency in Bulgaria's Schools: A Nonparametric Study

WPS1423 The Role of Commercial Banks in Entepprise Restructuring in Central and Eastem Europe

WPS1424 Terms-of-Trade Shocks and Optimal Luis Serven Investment: Another Look at the Laursen-Metzler Effect
Fareed M. A. Hassan

Contace

Date

for paper

Xiaoming Zhang

Heng-fu Zou

January 1995

G. Evans

85783

Martin Rama

Guldo Tabellini

Januay 1995

S. Fallon

38009

The World Bank

Legal Department

January 1995

K. Mathemová 82782

January 1995

Ren Ruoen

Sheoli Pargal

David Wheeler

Andrea Baranzini

Marc Chesney

Jacques Morisset

Lyn Squire

Sethaput Suthiwart-

Nanueput

Februany 1995

E. O'Rielly-Campbell 33707

E. Schaper 33457

February 1995

C. Dell 85148

Fobruary 1995

G. Bayard 37460

Martin C. Stowart-Smith

February 1995

N. James

82758

William T. Onorato

February 1995

W. Onorato

81611

February 1995

F. Smith 36072

February 1995

F. Smith 36072

Fobruany 1995

R. Gamer

Izabela Rutkowska

Zeljko Bogetic
Sajal Chattophadyay

Millard Long

Fobruary 1995

E. Khine

37471 
Policy Research Working Paper Series

\begin{tabular}{|c|c|c|c|}
\hline Title & Author & Date & $\begin{array}{l}\text { Contact } \\
\text { for paper }\end{array}$ \\
\hline $\begin{array}{l}\text { WPS1425 On the Intersectoral Migration of } \\
\text { Aaricultural Labor }\end{array}$ & $\begin{array}{l}\text { Donald Larson } \\
\text { Yair Mundlak }\end{array}$ & February 1995 & $\begin{array}{l}\text { J. Jacobson } \\
33710\end{array}$ \\
\hline
\end{tabular}

